University of Rhode Island

DigitalCommons@URI

Open Access Master's Theses

1986

\title{
A Study of Impact Fees: South Kingstown, Rhode Island
}

Elisa Ann Silverstein

University of Rhode Island

Follow this and additional works at: https://digitalcommons.uri.edu/theses

\section{Recommended Citation}

Silverstein, Elisa Ann, "A Study of Impact Fees: South Kingstown, Rhode Island" (1986). Open Access Master's Theses. Paper 690.

https://digitalcommons.uri.edu/theses/690

This Thesis is brought to you for free and open access by DigitalCommons@URI. It has been accepted for inclusion in Open Access Master's Theses by an authorized administrator of DigitalCommons@URI. For more information, please contact digitalcommons-group@uri.edu. 


\author{
A STUDY OF IMPACT FEES: \\ SOUTH KINGSTOWN, RHODE ISLAND \\ BY
}

ELISA ANN SILVERSTEIN

A RESEARCH PROJECT SUBMITTED IN PARTIAL FULFILLMENT OF THE REQUIREMENTS FOR THE DEGREE OF MASTER OF COMMUNITY PLANNING

UNIVERSITY OF RHODE ISLAND

1986 


\section{MASTER OF COMMUNITY PLANNING \\ RESEARCH PROJECT \\ OF}

ELISA ANN SILVERSTEIN

APPROVED:

Major Professorfforo H. Foeten $/$ Howard Foster

ACKNOWLEDGED:

Director ffows $t /$. Fosta 


\section{ACKNOWLEDGEMENT}

The completion of this thesis was dependent on the time and help given by various people. From the Town of South Kingstown, Anna Prager, the Town Planner, and Steve Alfred, the Town Manager gave me the initial direction for my thesis, without which the document may not have been started, as well as subsequent aid and information, enabling the completion of the thesis. In addition, Cynthia collins, Town Solicitor, Alan Lord, Finance Director, and Gaytha Langlois, Town Councilwoman offered the data and guidance necessary for the document's completion. Finally, I'd like to acknow ledge Barney Heath, Dr. How ard Foster and Dr. Farhad Atash for their help in research for and revision to the document. My sincere thanks to all those involved. 


\section{DEDICATION}

I dedicate this thesis, all the energy and all the work involved in writing it, to my parents, Dr. Albert Silverstein and Dr. Myrna Silverstein. Without their patience, love and encouragement this thesis would have remained a concept, and now its existence is dedicated to them with love and admiration. 
CONTENTS

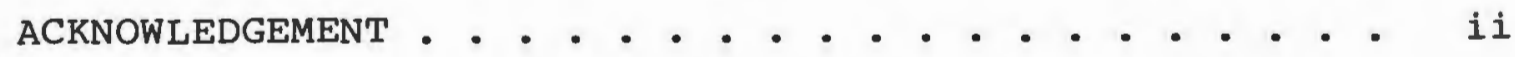

DEDICATION . . . . . . . . . . . . . . . . . .

Chapter

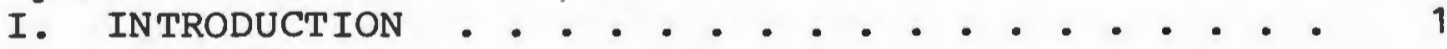

I. NATIONAL AND STATE TRENDS . . . . . . . . . . 8

III. PROFILE OF SOUTH KINGSTOWN . . . . . . . . . 16

IV. THE LEGAL ISSUE REGARDING IMPACT FEES • • • • • . 37

V. CASE STUDY . . . . . . . . . . . . . . 53

VI. CONCLUSIONS . . . . . . . . . . . . . . . 69

VII. RECOMMENDATIONS . . . . . . . . . . . . . 79

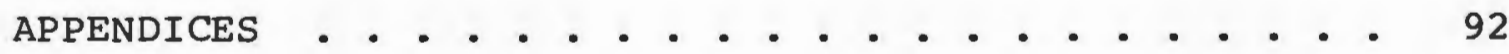

BILBIOGRAPHY • . . . . . . . . . . . . . . . 105 
1. National Enrollment Figures, 1970-1990 .... 10

2. Racial Breakdown of Population, South Kingstown, 1980 . . . . . . . . . . 18

3. Income Groups, South Kingstown, 1980 . . . . . . 20

4. Total Enrollment of Public Schools, South Kingstown, 1975-1985 ... . • . • . • . . 27

5. Enrollment Projections through 1994-95, South

6. Comparative Analysis of Elementary school

Enrollments in South Kingstown, by Schools . . 30

7. Capital Outlay for the South Kingstown School System, $1979 / 80$ to $1985 / 86$. . . . . . . 32

8. Linear Feet of Street in Phasing, Sweet Allen Farm . . . . . . . . . . . . 57

9. Annual Additions to school Population, Sweet

Allen Farm ............... . 61

10. Net Fiscal Impact: 1986-1994, Sweet Allen Farm . 62 


\section{LIST OF FIGURES}

1. Rhode Island Public School Expenditures, 1983 . . . 12

2. Single Family Residential Building Permits Issued, South Kingstown, 1970-85 . . . . . . . . . . 23

3. Correlation Between School Enrollment and Residential Development, South Kingstown, 1980-1985 . . . . . . . . . . . . 25

4. Comparison of School Enrollment and Per Pupil Contribution, South Kingstown, 1975-1985 . . . 35 


\section{CHAPTER I}

\section{INTRODUCTION}

Recent years have seen a dramatic decrease in federal and state aid to local governments. The current result is an inability on the parts of these localities to maintain and expand publically-provided infrastructure. Historically municipalities depended upon outside aid to maintain such basic local facilities as public schools. Roughly 35 to 45 percent of local school budgets are subsidized by federal and state funds. Yet as these sources of revenue disappear, local government is forced to sustain the burden of providing sufficient local facilities and services without the aid it relied upon in the past. Local government reliance on federal and state aid is surpassed in many states by its dependence on revenue from local property tax. Throughout the country local monetary contribution to public education (from property tax revenue) amounted to approximately 48 percent of local school budgets between 1978 and 1979. ${ }^{1}$ However, increasingly more state legislatures are placing restrictions on municipalities' ability to levy property taxes. ${ }^{2}$ Thus, while state and federal subsidization decreases so does the municipality's 
ability to make up the deficit.

Localities are faced with the challenge of

determining innovative means of raising revenue, means which adequately replace traditional sources of funding while remaining fair to community residents. Of the various means considered by local government officials, impact fees appear the most widely considered and utilized. They supply local governments with greater potential of raising revenue than any other exaction, tax or fee. Impact fees fund facilities and services specifically required by new development, funding not common to subdivision requirements or administrative fees. Since new development creates additional strain on existing local infrastructure, impact fees help shift some of the financial burden onto those responsible, ultimately the new resident homeowners. Generally, fees differ from taxes in that they are variable, determined by actual use, and are intended ultimately to benefit only the contributing population (or the "users"), not the entire community. Conversely, taxes are flat rates, without regard to actual use, and benefit the community as a whole. More specifically, impact fees include charges against new development for the purpose of defraying the costs of basic public services. The fee directly reflects the impact made on specified facilities by a particular type of development. For example, most dramatically affected by residential development in a 
community is the local school system. Thus, the developer or landowner is charged an appropriate fee (typically based on the number of school-age children introduced into the community), to be used in funding capital expansion of the school facility necessitated by the new development. A number of legal authorities believe that developers may be charged fees to offset the impacts of their projects on public facilities if the fee is demonstrably related to an impact of the proposed development and the resulting revenue is used directly to mitigate that impact. ${ }^{3}$ This requirement to "earmark" revenue raised from impact fees has appeared in landmark cases which ultimately set legal guidelines and precedents regarding the use of impact fees.

Two states in particular have proved the most advanced in their use of impact fees. California and Florida have seen a large number of their local governments employ impact fees as a means to raise revenue. In California the primary issue is less whether or not to impose impact fees and more which process localities should use when levying a charge on new development. In other words, in which stage of the approval process the developer is required to pay a fee becomes critical in assessing the validity of the fee. California's innovative legislature has approved the concept of impact fees. In one case, however, the court ruled that a fee could not be imposed as 
a condition for proposal approval. 4 As long as the fee is not an attempt to regulate permits or project approvals, it is deemed valid by the California courts, even if its primary function is to raise revenue. In addition, local governments have been permitted to spend the revenue from impact fees however and wherever they deem necessary, regardless of what the fees were levied for.

Florida contains a large number of communities utilizing impact fees to raise revenue for improvements necessitated by new development. A court ruling in 1975 became a precedent that has been applied in both subsequent court cases and locally drafted ordinances. The Dunedin case saw the court validate a local ordinance with certain modifications to the original ordinance. ${ }^{5}$ Initially the court found the Dunedin ordinance defective in its failure to specify the expenditure of revenue raised from impact fees. Dunedin officials subsequently amended the ordinance to earmark the impact funds for water and sewer system expansion. In the Dunedin case, the Florida supreme Court established the "Dunedin Rule," used as guidelines for local governments and a reference in subsequent court cases involving impact fees. The guidelines were as follows:

1. New development must necessitate that the present system of public facilities be expanded.

2. The fees imposed on the users must be no more than the costs the local government would incur 
in expanding the system.

3. The fees must be expressly earmarked and spent for the purposes for which they were charged.

The Dunedin case has been referred to in a number of fee-related cases in Florida. ${ }^{6}$ If a local ordinance or fee schedule complies with the aforementioned guidelines, it is validated by the courts and held legal. Thus, Florida and California vary greatly in their definitions of the legality of impact fees. California stresses the way in which the fee is imposed; is plat approval based on payment of the impact fee? Florida courts have focused on the allocation of revenue expenditure; is the revenue raised from impact fees funding facility expansion necessitated by new development?

Different regions throughout the United States seem to emphasize and focus on particular issues regarding the imposition of impact fees. In the Pioneer Trust case in Illinois, the primary issue was whether or not the proposed residential development necessitated the expansion of the existing school facilities. 7 In Patterson v. Alpine City, the court invalidated a fee which placed unreasonable financial burden on new residents. 8

As traditional funding sources and practices become extinct and improbable, local government officials realize the dire conditions under which they are forced to maintain 
public facilities and services. Federal aid to state budgets and programs is dwindling, and municipal governments suffer from the states' depleted funds as state-provided funding decreases at an increasing rate. Furthermore, restrictions are being placed on local governments' authority to collect property tax. The dramatic loss of historically prevalent funding is matched by the increasing rate of growth in many communities, as fuel prices stabilize and populations are more willing to commute to their jobs. This thesis addresses the issue of the depletion of traditional means of raising revenue in a growing community, South Kingstown, Rhode Island. The study investigates the potential of that community employing impact fees as a means of increasing revenue in the local budget. Specifically, the impact of residential growth on the Town's public school system is determined, and the possibility and success of imposing impact fees on residential development evaluated.

The individual chapters in this thesis differ according to each one's scope of investigation of impact fees. Chapter Two describes national and state trends regarding school enrollment trends and projections and state educational spending. The next chapter describes the Town of South Kingstown and establishes a level of need for the imposition of impact fees on residential development. Chapter Four investigates the legality of impact fees, using relative past court cases as a model for the 
present legal acceptance of fees. In the fifth chapter, the application of an impact fee on a cluster housing development in South Kingstown is reviewed thoroughly in order to assess the "success" of an education impact fee in Town. And finally, conclusions are drawn and recommendations made utlilzing the information in this thesis as a foundation. 
CHAPTER TWO

NATIONAL AND STATE TRENDS

This chapter is a comprehensive review of basic historical trends of school enrollment and spending related to education. Both national and state trends are included to establish a model for evaluating South Kingstown's situation. Further, recently passed state legislation is reviewed in preparation for an analysis of South Kingstown's financial stability in the future.

The localities in this country are experiencing a variety of monetary difficulties and cutbacks. Yet current national trends in school enrollment indicate significant increases in school-age children. This trend places pressure on local school systems to both maintain present facilities and expand the overall facility to sufficiently provide schooling to the communities. This population increase is most significant at the elementary school level. From 1970 to 1980 the enrollment figure for the nursery and kindergarten level of education increased 21 percent. This figure is projected to increase another 33 percent by 1990 . While enrollment figures for kindergarten through 8 th grade have decreased 14 percent from 1970 to 1980 , the projections 
show a 9 percent increase by 1990 due to the current "bulge" in population at the kindergarten level. Conversely, the 912 grade enrollment figure increased slightly between 1970 and 1980 (by 1 percent); the projected 9-12 figures for 1990 indicate a decrease in enrollment by 16 percent. ${ }^{9}$ Table 1 delineates the changes in enrollment for three school categories: Nursery and kindergarten, K-12, and High School graduates. 10

Nationally, public education, including school debt service, consumes approximately two-thirds of municipal budgets. Local property taxes average 65 percent of total municipal revenue, while state government contributions to local revenue average 25 percent and federal contributions-typically in the form of CDBG funds--constitute 10 percent of municipal revenues. Thus, local governments are extremely dependent on local revenues to maintain public services and facilities. This reliance makes capital improvements on the local level very difficult, and the cutbacks in aid from both federal and state agencies further exemplify the dire situation ahead for most municipal governments.

Rhode Island's demographic figures show considerable changes over the past two decades. Between 1960 and 1980 the overall population in Rhode Island increased 10.2 percent. The state's total population in 1980 was $947,154.11$ In 1983 approximately 137,933 students were 
TABLE 1

NATIONAL ENROLLMENT FIGURES, 1970-1990

(IN THOUSANDS)

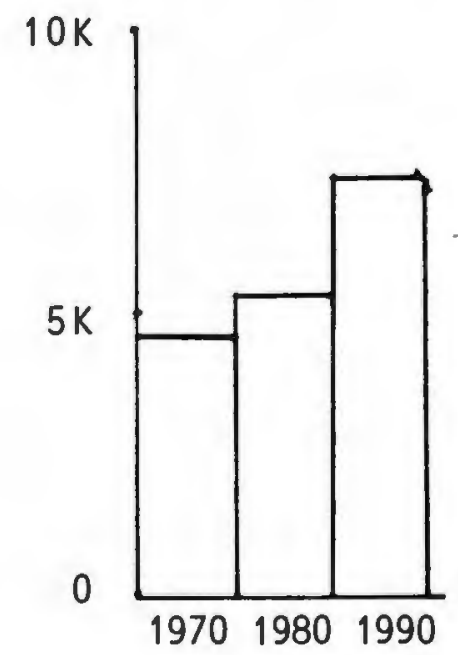

Nursery and Kindergarten

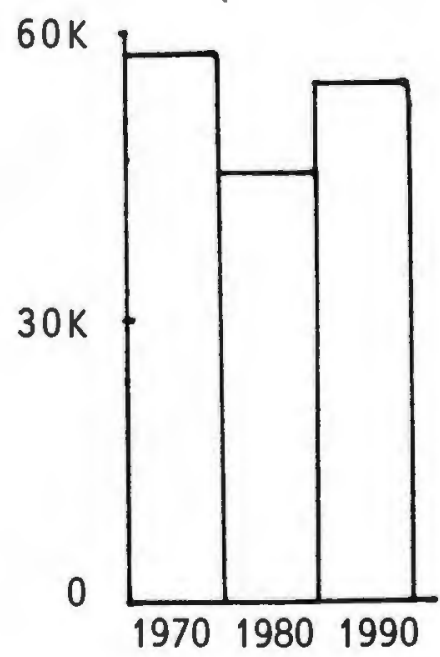

$\mathrm{K}-12$

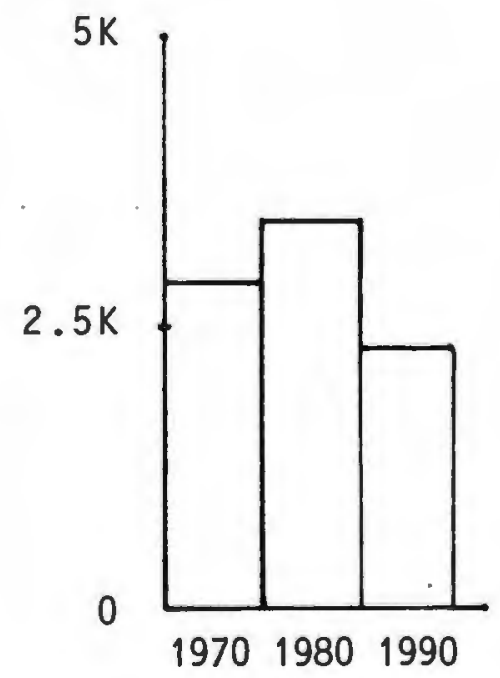

High School Graduates

SOURCE: Projections of Education Statistics to 1990-91, Vol. 1, National Center for Education Statistics, Washington, D.C. 
enrolled in the public school systems throughout the state. As the state average, $\$ 3,058$ was spent per pupil; thus the state spent over $\$ 4.2$ million, or roughly 84 percent of total tax revenue, on education in 1984. Furthermore, individual communities spent over 50 percent of their property tax revenue on education. 12

The $\$ 420$ million state expenditure for public schools was financed by four sources. Most significant was the local tax support which provided over $\$ 251$ million--or 60 percent of the necessary funds--for education. State aid, in the form of earmarked grants, supported local school systems with better than $\$ 157$ million (37 percent). Departmental revenue--charges for services by local government departments--contributed $\$ 7.4$ million $(2$ percent), while federal grants provided another $\$ 5.3$ million $(1$ percent) to the state to fund local school departments. Figure 1 illustrates the monetary breakdown of public school financing. 13

Recently state officials evaluated past and current trends of local property tax revenue. The significant annual increases alarmed the legislature and their findings elicited a recent campaign to curb local governments' ability to tax personal property, similar to that recently seen in Massachusetts. Information published by the Rhode Island Public Expenditure Council (RIPEC) showed an "overreliance" on property tax in Rhode Island. For example, in 


\section{FIGURE 1}

RHODE ISLAND

PUBLIC SCHOOL EXPENDITUAES

1983

(MILLIONS)

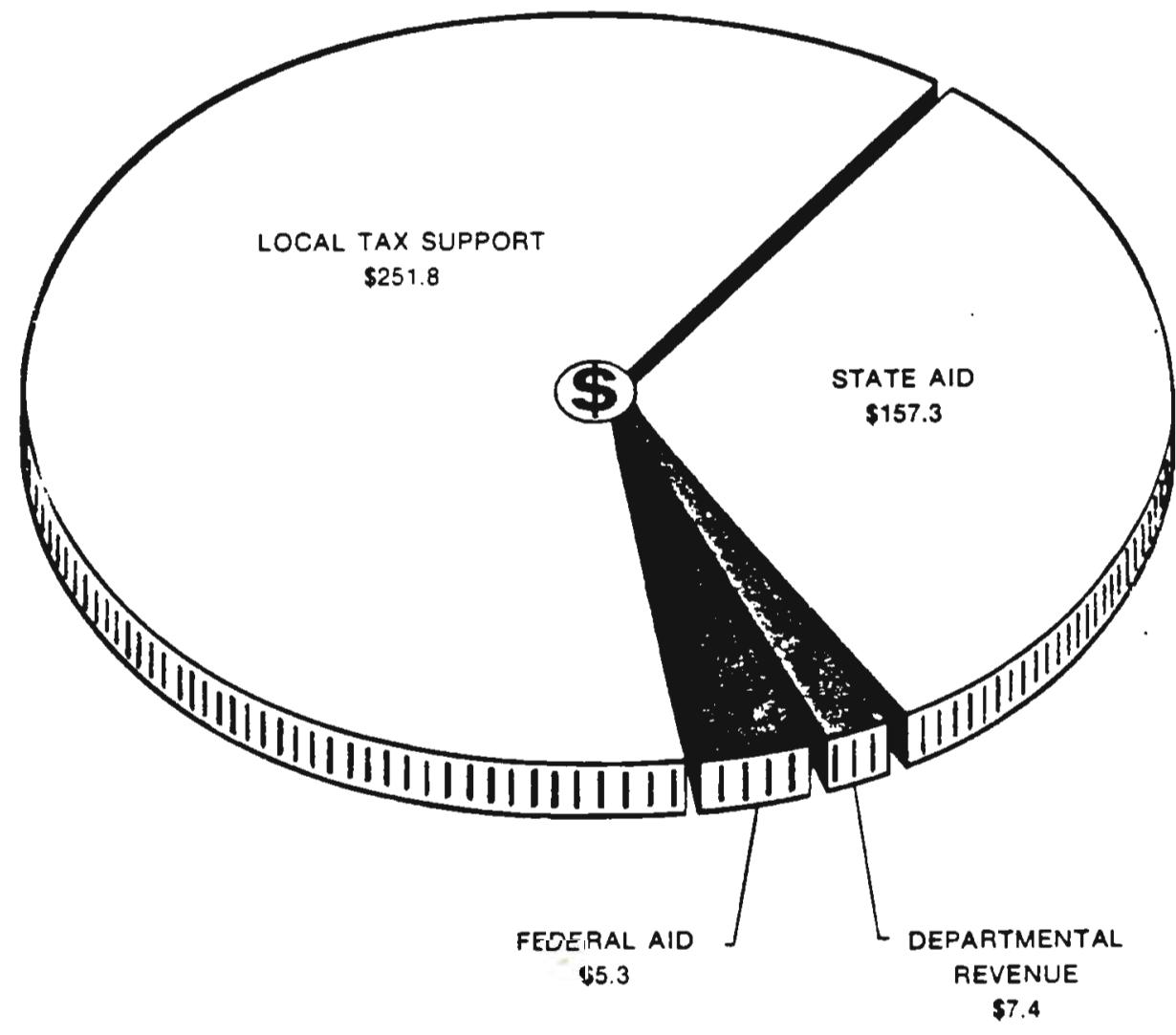

SOURCE: Annual State Report on Local Government Finances and Tax Equalization, Department of Community Affairs, 1984. 
1983 Rhode Island property tax collections were the sixth highest in the United States. In November of 1984 the House of Representatives in the state committed themselves to enacting a property tax relief and replacement program. During the 1985 session of the General Assembly, the State Legislature passed an important piece of legislation. Entitled "The Omnibus Property Tax and Replacement Act of 1985," the bill's primary provision was to increase state aid to both local governments and school districts. As a quid pro quo for this program, a 5.5 percent cap on property tax levies was imposed. In May 1986 the legislature amended the Omnibus Bill, easing some of the pressure placed on localities to decrease property tax levies. Yet the result of the newer legislation resembles that of the original bill. The object is apparent: limit the rate of growth in local property tax as a quid pro quo for additional state outlays. Ultimately this act controls--and perhaps limits-local expenditure. This bill could potentially aggravate the already-existing problem of identifying funds for basic municipal services and facilities. The Omnibus Bill further exemplifies the need for local governments to determine alternative means of raising revenue to the traditional federal and state aid and local collection of property taxes. Impact fees have been instituted as such a revenueraising technique in other states. But in Rhode Island the attempt to impose impact fees in communities has been 
limited to one incident. In the City of Cranston, local government officials attempted to impose an impact fee for the purpose of increasing the amount of recreational land in the city. ${ }^{14}$ The validity of the requirement that 7 percent of a project's land area be deeded to the city was tested in the Rhode Island Supreme Court. The court concluded that the "involuntary dedication of land is a valid exercise of police power only to the extent that the need for the land required to be donated results from the specific and unique activity attributable to the developer."15 The 7 percent dedication requirement was held by the court as "arbitrary on its face," and was invalidated. ${ }^{16}$ The end result of this solitary attempt to impose impact fees in this state is that the enabling legislation does not explicitly authorize municipalities to impose impact fees, but rather merely implies this power. Thus, the first--and only--impact fee ordinance in Rhode Island was viewed as inappropriate by the state supreme court.

South Kingstown has recently been the forerunner in numerous innovative land use controls, policies and preservation techniques. It is not surprising, therefore, that its officials are currently utilizing impact fees to recapture some of the funds lost due to federal and state cutbacks, as well as the 5.5 percent cap on property tax levies or tax rates. The following chapter describes the 
current demographic and economic conditions in South Kingstown. 
CHAPTER THREE

\section{PROFILE OF SOUTH KINGSTOWNN}

This chapter is a comprehensive view of the Town of South Kingstown. Demographic and economic data are compiled to deliver a complete image of the Town, including population, housing market, financial status and other characteristics.

The Town of South Kingstown, along with North Kingstown and Narragansett was originally a part of King's Town, purchased from the Narragansett Indians in 1674. The Town was incorporated as a separate municipality in 1723 .

Farming was the main occupation of the early colonists. But by the 1800's several textile mills had been founded. The textile manufacturing sector, however, declined in the Town soon after World War II.

Today, South Kingstown supports a substantial

commercial and service trade, localized in one central area. This concentration of commercial activity has allowed residential development to expand along the fringe of the retail area. Most residential growth has occurred in the Wakefield-Peace Dale area. In addition, former beach colonies along the waterfront--primarily Matunuck and Green 
Hill--gradually have become year-round communities.

Located in Washington County, South Kingstown is the largest town in area in Rhode Island. In its entirety the town is 62.3 square miles, of which 56.8 square miles is land area and 5.5 square miles is inland water. Roughly 33 percent of the land is cleared, with 13.4 percent urban and 18.4 percent devoted to agriculture. The town is in the southeastern portion of the state and has a large percentage of shoreline (although the town at this point does not own any part of it).

South Kingstown is located thirty miles from the state's capital city, Providence. It has developed into a major summer resort and recreational area. Its beaches and numerous fresh water fishing facilities attract a large vacationing and seasonal population. The town has experienced significant growth in both its summer tourist facilities and its year-round residential construction. The 1980 Census showed the town's population at 20,414 , a 20.7 percent increase over the 1970 Census population of 16,913 (which was 41.5 percent greater than the 1960 figure of 11,942 ). More than 94 percent of the 1980 population was white. Table 2 details South Kingstown's racial breakdown for 1980 .

The median age in South Kingstown was 24.3 years, whereas the Rhode Island median age was 31.7 , a difference of more than 7 years. This data is probably skewed, 
TABLE 2

RACIAL BREAKDOWN OF POPULATION, SOUTH KINGSTOWN, 1980

\begin{tabular}{|c|c|c|c|c|c|c|}
\hline $\begin{array}{c}\text { Total } \\
\text { Population }\end{array}$ & White & Black & $\begin{array}{l}\text { American } \\
\text { Indian }\end{array}$ & Asian & Other & $\begin{array}{l}\text { Spanish } \\
\text { Origin }\end{array}$ \\
\hline $\begin{array}{ll}\# & 20,414 \\
8 & 100\end{array}$ & $\begin{array}{c}19,259 \\
94\end{array}$ & $\begin{array}{c}329 \\
2\end{array}$ & $\begin{array}{c}398 \\
2\end{array}$ & $\begin{array}{c}262 \\
1\end{array}$ & $\begin{array}{l}136 \\
.6\end{array}$ & $\begin{array}{l}167 \\
.8\end{array}$ \\
\hline
\end{tabular}

SOURCE: Census of Population, U.S. Bureau of the Census, 1980 . 
however, since the student population at the University of Rhode Island (URI) is included in the Census questionnaire population. However, overall the town's median age in 1980 was more than 23 percent younger than the state average. In South Kingstown the median family income in 1979 was $\$ 21,302$, an increase of more than 111 percent over the 1969 average of $\$ 10,052$. Furthermore, the 1979 figure was 10 percent greater than the state's median family income that year. Table 3 describes the Census income categories and the number and percentage of families in South Kingstown that fall within each category. The income group which contained the most significant number of families was $\$ 17,500$ to $\$ 24,900$. Nearly 24 percent of South Kingstown's families appeared here. The following category-- $\$ 25,000$ to $\$ 34,900$--contained 21.6 percent of the families in town. Finally, 17.8 percent of the families fell in the highest income group: $\$ 35,000$ and above. Although the town appears wealthy, particularly when compared with the state as a whole, it does contain a wide range of income levels. Yet the variation in income levels appears insignificant when reviewing solely the median rent and median house value in South Kingstown. The Town's median monthly rent is $\$ 198$, as opposed to the $\$ 158$ median rent for the state. Furthermore, the median sales price for a home in South Kingstown is $\$ 53,900,15$ percent greater than the state average of $\$ 46,800$. 
TABLE 3

INCOME GROUPS

SOUTH KINGSTOWN, 1980

\begin{tabular}{rrr}
\hline & $\#$ & 8 \\
\hline Total \# families & 4,319 & 100.0 \\
$7,500-12,499$ & 369 & 8.5 \\
$12,500-17,499$ & 560 & 13.0 \\
$17,500-24,999$ & 653 & 15.2 \\
$25,000-34,999$ & 1,034 & 23.9 \\
& 934 & 21.6 \\
\hline
\end{tabular}

SOURCE: Census of Population, U.S. Bureau of the Census, 1980 . 
The number of housing units in South Kingstown in 1980 was 25 percent greater than that in 1970. In 1980 there were 8,138 units versus 6,020 in 1970. Furthermore, the state experienced only a 17 percent increase in housing units from 1970 to 1980. The owner-occupancy rate in the town in 1980 was 70.5 percent, significantly higher than the state's figure of 58.8 percent.

In 1983 residential property in South Kingstown contributed 66.84 percent of total property tax on tangible property. Comparatively, the state average was 63.5 percent. The tax levied in the town in 1983 amounted to $\$ 12,186,064$.

Subdivision activity in South kingstown has increased dramatically. Further, construction of new single family homes is among the highest in the state. South Kingstown has been experiencing significant increases in development, as evidenced by the number of building permits issued, as well as residential property sales. From 1982 to 1983, sales increased by roughly 79 percent. By 1984 these sales had increased another 16 percent. They appear to have levelled off in 1985, but the trend of increasing sales is expected to continue as interest rates stabilize, large lots continue to be subdivided into smaller residential lots for single family homes, and seasonal residential areas become year-round.

Over the past five years South Kingstown has 
experienced a great increase in the number of residential building permits issued. By October 1985, the town has issued 136 permits for single family units, a 43 percent increase of the 95 permits issued in 1980. Figure 2 shows the actual number of building permits issued from 1970 to 1985. From 1980 to 1985 , the town averaged 128.4 single family dwelling units built each year. According to the 1980 Census, South Kingstown had 5,843 occupied dwelling units, with 2.74 persons per household. Thus as an annual average, South Kingstown has an inmigration rate of 352 persons. To estimate the number of students generated by residential growth, the total school enrollment $(2,871$ in $1985)$ is divided by the total number of occupied dwelling units $(5,843$ in 1980), plus the annual average multiplied by five years, for the 1985 estimate of occupied units. This proportion yields an estimate of .44 students per dwelling unit. Multiplied by the annual average of single family units built $(128.4)$, this per dwelling unit estimate suggests that 56.5 students will be added to the school system each year. The calculations are listed below:

$$
\begin{aligned}
& 128.4 \times 2.74= \begin{array}{c}
352 \text { persons migrate into the town } / \\
\text { year }
\end{array} \\
& \frac{2,871}{6,485}=.44 \text { students/unit } \\
& 128.4 \times .44=\begin{array}{c}
56.5 \text { students added/year due to } \\
\text { residential growth }
\end{array}
\end{aligned}
$$




\section{FIGURE 2}

\section{SINGLE FAMILY RESIDENTIAL}

BUILDING PERMITS ISSUED,

SOUTH KINGSTOWN, 1970-85

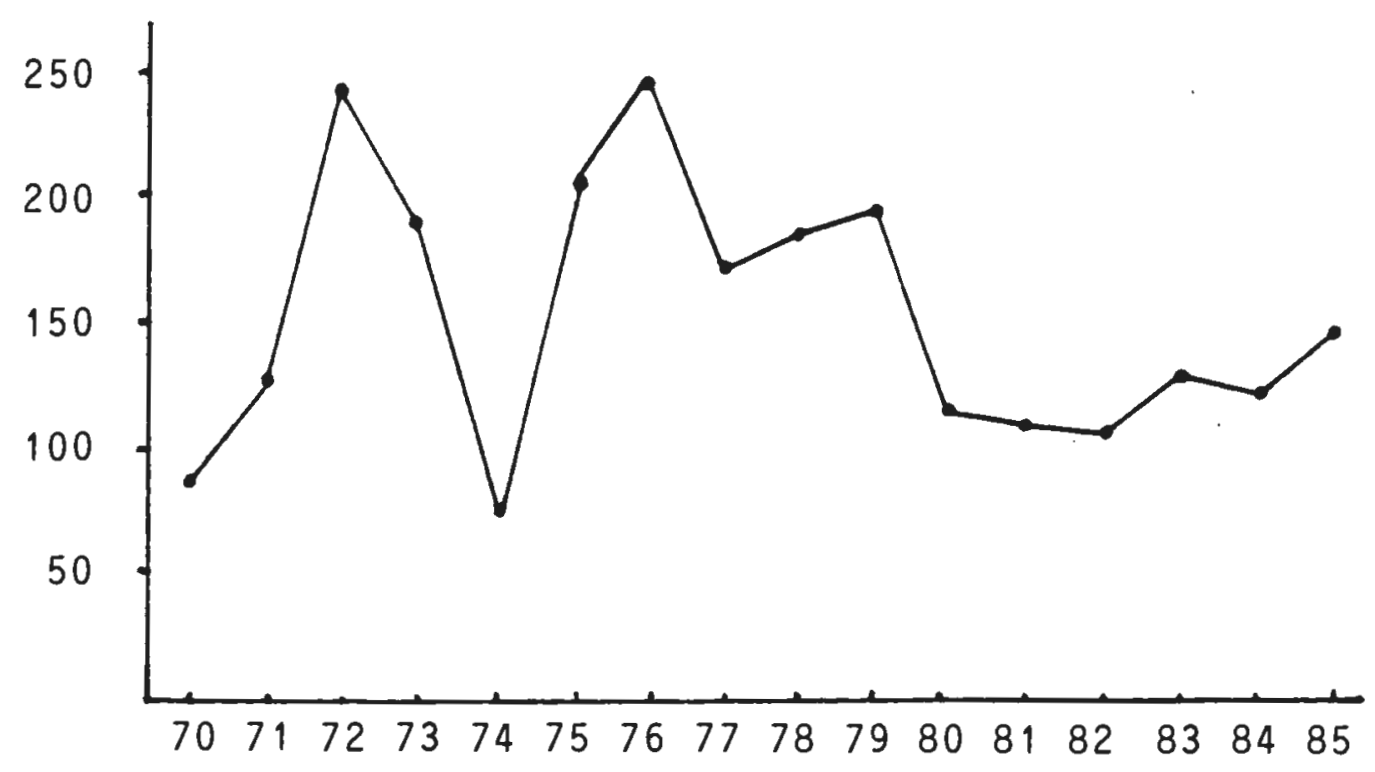

SOURCE: South Kingstown Building Permits Records. 
The Town of South Kingstown School Department consists of nine schools: six elementary schools (k-6), one separate kindergarten, one junior high school (7 and 8), and one senior high school (9-12). The town is divided into school districts allocating where the children shall attend elementary school. Recently, however, a number of the elementary schools have been forced to bus their children to other schools due to a shortage of classroom space.

As South Kingstown attracts new residents the strain on its infrastructure intensifies. specifically, the population which appears prevalent among new residents is young families with elementary school-age children. Simultaneously, the increased population of children aged 5 through 10, or kindergarten through fifth grade, has been significant in the last year. Population peaks of school-age children are typical. And recently the bulge appears at the elementary level. There exists a strong correlation between residential development and school enrollment. Figure 3 shows that the patterns of both permits issued and school population over the last five years are unmistakably similar. 17

The enrollment trends in South Kingstown, although not major, do affect the demand on existing school facilities. Since 1975 total enrollent has decreased by 285 students. Yet enrollment began to increase by 1982, and in 1985 the school system experienced another increase, this 


\section{FIGURE 3}

CORRELATION BETWEEN SCHOOL ENROLLMENT

AND RESIDENTIAL DEVELOPMENT,

SOUTH KINGSTOWN, 1980-1985

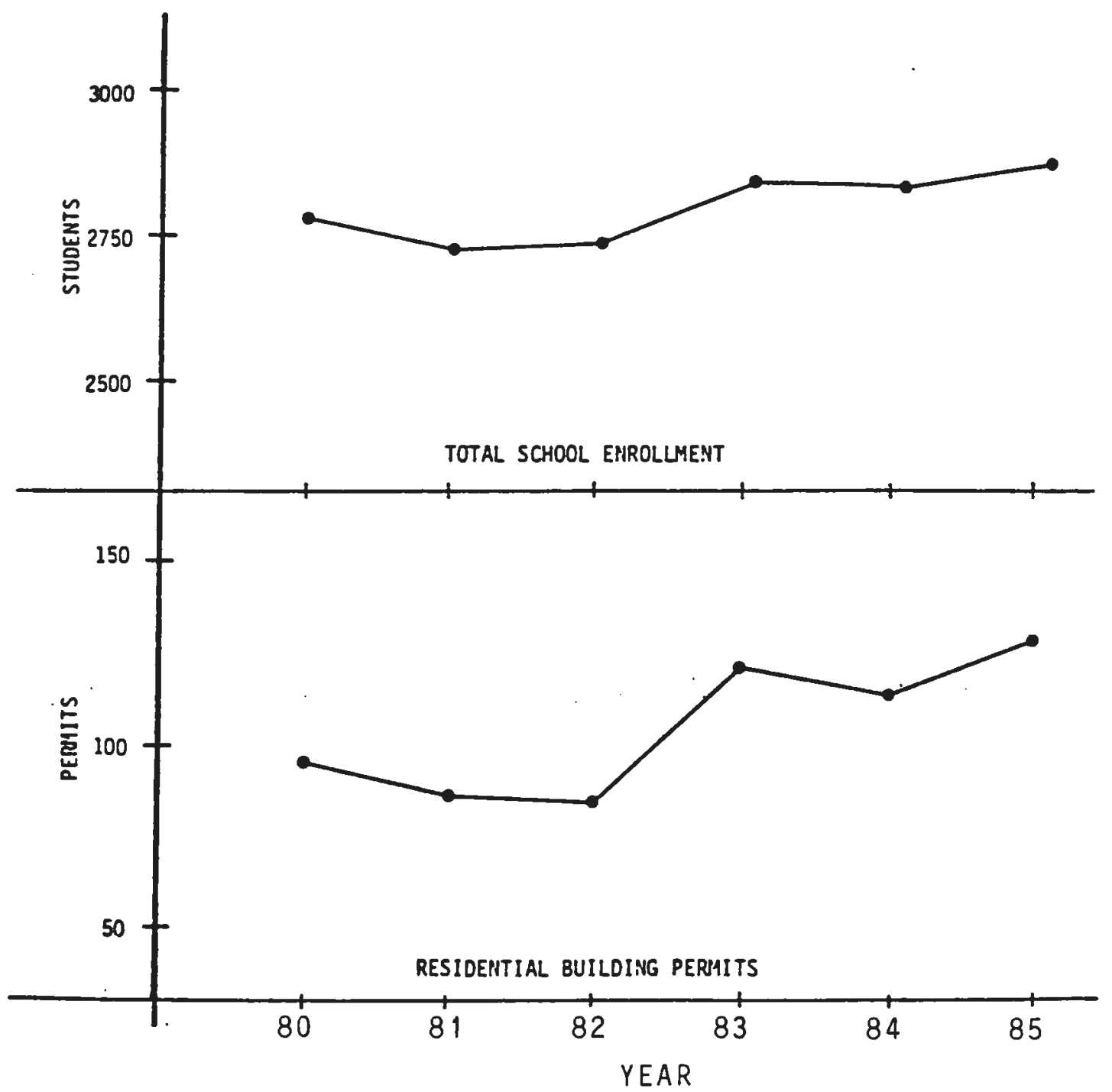

SOURCE: Preliminary Comprehensive Plan, Wilbur Smith Associates, 1985. 
one being over 100 students. Table 4 displays the total annual enrollment patterns. Furthermore, the table shows significant variations in enrollment from year to year. For example, in 1975 the largest number of students was attending the junior high school. By the early 1980's this peak had shifted to the senior high school. And in 1985 enrollment figures show a significant enrollment increase at the elementary level.

These population variations in the public school system are significant because they indicate future facility needs. The present student increase at the elementary level indicates a greater demand at the secondary level in the near future. Thus, the slowed increases in enrollment in the junior and senior high schools in 1985--and the projected decreases through 1990--are deceiving; by the 1991-92 school year both secondary schools will have experienced significant enroliment increases. Currently the high school is designed for capital expansion. Added enrollment will only intensify the need for expansion. Table 5 lists the projections for school enrollment in South Kingstown calculated by the Rhode Island Department of Education (RIDOE). By 1994-95, a projected 139 students at the junior high level and 70 at the senior high level will be added to the public school enrollment.

When calculating future enrollment figures it is essential that existing facility capacity be considered in 
TABLE 4

TOTAL ENROLLMENT OF PUBLIC SCHOOLS, SOUTH KINGSTOWN, 1975-1985

\begin{tabular}{|c|c|c|c|c|c|c|c|c|c|c|c|}
\hline & 1975 & 1976 & 1977 & 1978 & 1979 & 1980 & 1981 & 1982 & 1983 & 1984 & 1985 \\
\hline K & 226 & 197 & 193 & 204 & 203 & 206 & 194 & 208 & 228 & 215 & 225 \\
\hline 1 & 215 & 207 & 209 & 190 & 193 & 187 & 204 & 203 & 212 & 234 & 230 \\
\hline 2 & 226 & 212 & 191 & 201 & 182 & 171 & 166 & 187 & 191 & 197 & 231 \\
\hline 3 & 206 & 205 & 215 & 180 & 186 & 195 & 170 & 153 & 187 & 187 & 191 \\
\hline 4 & 216 & 200 & 201 & 212 & 188 & 179 & 195 & 180 & 156 & 175 & 185 \\
\hline 5 & 192 & 207 & 187 & 212 & 230 & 191 & 189 & 195 & 184 & 166 & 183 \\
\hline 6 & 278 & 211 & 207 & 188 & 213 & 229 & 211 & 194 & 194 & 187 & 161 \\
\hline 7 & 252 & 269 & 219 & 215 & 192 & 218 & 246 & 230 & 209 & 202 & 203 \\
\hline 8 & 271 & 261 & 164 & 221 & 219 & 202 & 222 & 254 & 234 & 211 & 219 \\
\hline 9 & 262 & 263 & 278 & 281 & 250 & 232 & 218 & 231 & 262 & 245 & 222 \\
\hline 10 & 225 & 217 & 262 & 228 & 231 & 226 & 206 & 195 & 222 & 238 & 240 \\
\hline 11 & 206 & 212 & 172 & 223 & 211 & 211 & 208 & 200 & 185 & 197 & 209 \\
\hline 12 & 266 & 197 & 193 & 174 & 215 & 204 & 206 & 218 & 200 & 181 & 210 \\
\hline Ungraded & 54 & 51 & 49 & 80 & 68 & 79 & 90 & 91 & 74 & 103 & 162 \\
\hline TOTALS & $\overline{3095}$ & $\overline{2909}$ & $\overline{2840}$ & $\overline{2809}$ & $\overline{2781}$ & $\overline{2730}$ & $\overline{2725}$ & $\overline{2739}$ & $\overline{2738}$ & $\overline{2738}$ & $\overline{2871}$ \\
\hline
\end{tabular}

SOURCE: South Kingstown School Department.

Note: Includes pre-kindergarten, pre-one, special education and tuition students. 
TABLE 5

ENROLLMENT PROJECTIONS THROUGH 1994-95, SOUTH KINGSTOWN

\begin{tabular}{lllll}
\hline & K-6 & $7-8$ & $9-12$ & Total \\
\hline $1985 / 86$ & 1462 & 404 & 854 & 2720 \\
$1986 / 87$ & 1549 & 382 & 833 & 2764 \\
$1987 / 88$ & 1612 & 378 & 789 & 2779 \\
$1988 / 89$ & 1654 & 406 & 741 & 2801 \\
$1989 / 90$ & 1699 & 423 & 731 & 2853 \\
$1990 / 91$ & 1734 & 448 & 740 & 2922 \\
$1991 / 92$ & 1760 & 485 & 753 & 2998 \\
$1992 / 93$ & 1758 & 528 & 805 & 3091 \\
$1993 / 94$ & 1758 & 556 & 856 & 3170 \\
$1994 / 95$ & 1767 & 543 & 924 & 4234 \\
\hline
\end{tabular}

SOURCE: Rhode Island Department of Education. 
order to assess the potential impact on the present school facilities. According to contract agreement, the maximum capacity of children per classroom is 25 in a "split" grade and 27 in a straight grade. These figures, when multiplied by the number of classrooms in each school, render the student capacity of each building. Table 6 shows actual capacity and enrollment of each elementary school in the South Kingstown school system.

Apparently two elementary schools in South Kingstown reached capacity as of the 1984-85 school year: Matunuck and Hazard Schools. A direct correlation exists between the enrollment concentration and the large increases in building starts. (Please refer to Figure 3 for the specific relationship that exists). Examination of building permit records for 1984 and 1985 indicates that nearly 30 percent of all permits issued were in the Matunuck Elementary School district, while approximately 12 percent of the total number of permits were issued in the area of Hazard Elementary School. ${ }^{18}$

As the number of school-age children increases steadily in South Kingstown the school system experiences a need for additional classrooms. And while capital outlay has not represented a significant percentage of the school budget thus far, it appears more and more significant when one projects into the future. The existing facilities are near or at capacity now. With the impending increases in 
TABLE 6

COMPARATIVE ANALYSIS OF ELEMENTARY SCHOOL ENROLLMENTS IN SOUTH KINGSTOWN, BY SCHOOLS

\begin{tabular}{|c|c|c|c|c|c|c|c|}
\hline \multirow{2}{*}{$\begin{array}{l}\text { School } \\
\text { Building }\end{array}$} & \multicolumn{3}{|c|}{ Actual Capacity } & \multirow{2}{*}{$\begin{array}{l}\text { Resident } \\
\text { \#Stud. }\end{array}$} & \multirow{2}{*}{$\begin{array}{l}\text { Students } \\
\text { sage }\end{array}$} & \multirow{2}{*}{$\begin{array}{c}\text { Actual } \\
\text { \#Stud. }\end{array}$} & Enrollment ${ }^{d}$ \\
\hline & \#Rms. & \#Stud. & zage & & & & zage \\
\hline $\begin{array}{l}\text { Hazard } \\
\text { Matunuck } \\
\text { Peacedale } \\
\text { South Road } \\
\text { Wakefield } \\
\text { West Kingston } \\
\text { Stepping Stones }\end{array}$ & $\begin{array}{r}10 \\
9 \\
11 \\
15 \\
14 \\
9 \\
2\end{array}$ & $\begin{array}{l}200 \\
220 \\
200 \\
363 \\
338 \\
220 \\
100\end{array}$ & $\begin{array}{l}12.98 \\
14.38 \\
12.98 \\
23.68 \\
21.98 \\
14.08\end{array}$ & $\begin{array}{l}180 \\
281 \\
240 \\
303 \\
276 \\
195\end{array}$ & $\begin{array}{l}12.28 \\
19.18 \\
16.38 \\
20.58 \\
18.78 \\
13.28\end{array}$ & $\begin{array}{l}151 \\
225 \\
267 \\
307 \\
291 \\
219\end{array}$ & $\begin{array}{l}10.38 \\
15.48 \\
18.38 \\
21.08 \\
9.98 \\
15.08\end{array}$ \\
\hline TOTALS & $70^{a}$ & $154 i$ & $99.9 \%$ & 1475 & 100.08 & 1460 & 99.98 \\
\hline
\end{tabular}

SOURCE: South Kingstown Elementary Enrollment Task Force.

Notes: (a) Minus 13 Rooms for Special programs = 57 regular classrooms.

(b) Plotkin Report, Summer 1985.

(c) Superintendent's Office, Fall 1985 (September). Does not include special education students.

(d) Superintendent's Offide, Fall 1985 (November). 
school enrollment in the future, the current pressures on the school system will only intensify. Please refer to Table 6 for the actual capacities of each elementary school in the town.

The dollars allocated to capital outlay in the schools have fluctuated from the 1979-80 school year to the present. Overall, however, the capital expenditure appears relatively stable. As demonstrated in Table 7 , the capital outlay figure increased 41 percent from the 1981-82 to the 1982-83 school years. However, that figure decreased 90 percent by the 1983-84 school year. While the allocated capital funds seem to balance overall, such funds have not increased proportionally to the total school budget. The proposed 1985-86 budget shows that while the overall budget increased 76 percent over that in 1979-80, capital expenditure increased only 46 percent. Furthermore, capital outlay currently constitutes only 1.5 percent of the school department budget.

These data illustrate two significant issues;

firstly, relatively small amounts of money have been allocated to capital improvements to the school system, whether this is due to a lack of need or a lack of funds is unknown. Secondly, the need for increased capital outlay funding becomes increasingly apparent as present facilities can no longer support the community's needs for such. Thus, the historical percentage of allocated funds for capital 
TABLE 7

CAPITAL OUTLAY FOR THE SOUTH KINGSTOWN SCHOOL SYSTEM, $1979 / 80$ TO $1985 / 86$

\begin{tabular}{lrrr}
\hline & $\begin{array}{c}\text { Total } \\
\text { Capital } \\
\text { Outlay } \\
\text { Budget }\end{array}$ & $\begin{array}{c}\text { 8े } \\
\text { Total } \\
\text { Budget }\end{array}$ \\
\hline $1979 / 80$ & 127,669 & $6,849,351$ & 1.9 \\
$1980 / 81$ & 67,389 & $7,865,209$ & .8 \\
$1981 / 82$ & 139,121 & $8,645,272$ & 1.6 \\
$1982 / 83$ & 195,451 & $9,552,950$ & 2.0 \\
$1983 / 84$ & 169,869 & $10,250,662$ & 1.7 \\
$1984 / 85$ & 169,622 & $11,000,158$ & 1.5 \\
$1985 / 86^{\star}$ & 182,909 & $11,824,616$ & 1.5 \\
\hline
\end{tabular}

SOURCE: Preliminary Comprehensive Plan, Wilbur Smith Associates, 1985.

* Proposed budget. 
improvement would be grossly insufficient if applied today. Other factors exist in addition to the increasing enrollment patterns and building starts regarding the future of the school system in South Kingstown. Of primary importance is the Town's ability to tax personal property. of all revenue allocated to public schools in 1984, property tax revenue constituted 70 percent. Statewide, property tax revenue only equalled 60 percent of the total public school expenditure figure. ${ }^{19}$ Thus, south Kingstown depends more heavily on revenue from property taxes than the state as a whole.

The passage of the Omnibus Bill affects the Town dramatically. By limiting the local tax levy, the legislature has decreased actual funds necessary to maintain South Kingstown's current school system, not to mention the essential capital improvements and additions. The bill restricts communities' abilities to tax, restricting either the tax levy or the rate.

In a growing community like South Kingstown, this restriction potentially forces the local government to decrease the tax rate in order to restrict the revenue made from property tax to a 5.5 percent increase over the previous year. This situation could arise if a significant number of new property owners migrate into the community, which appears very likely. Unfortunately the costs to the Town as a result of new development do not decrease with the 
tax rate. Providing basic services and facilities remains as intense as the year before, if not more.

The effect of the Omnibus Bill is most dramatic in communities such as South Kingstown, where its wealth threatens its potential to receive state aid, regardless of any loss of traditional funding sources. The Town does not qualify for additional financial aid due to its wealth and will continue to receive the minimum school aid funding it receives presently, constituting 27 percent of actual school-related costs. Ultimately, federal aid cutbacks threaten the financial stability of the South Kingstown school department. Federal grants for the Town's schools accounted for only 1 percent of all school funding in 1984.20 Yet 80 percent of the general budget goes to the schools. Therefore, federal cutbacks to other local and state agencies affect the school budget directly. The provision of education is the most costly of all public services and facilities, and in South Kingstown 64 percent of total expenditure is school-related.

In 1979, although total enrollment had decreased, the per pupil cost for the Town dramatically increased. Figure 4 shows the relationship between school enrollment and per pupil expenditures. By the 1985-86 school year the pattern of local per pupil expenditure could surpass total enrollment patterns, and continue to increase similarly to 


\section{FIGURE 4}

COMPARISON OF SCHOOL ENROLLMENT

AND PER PUPIL CONTRIBUTION,

SOUTH KINGSTOWN, 1975-1985

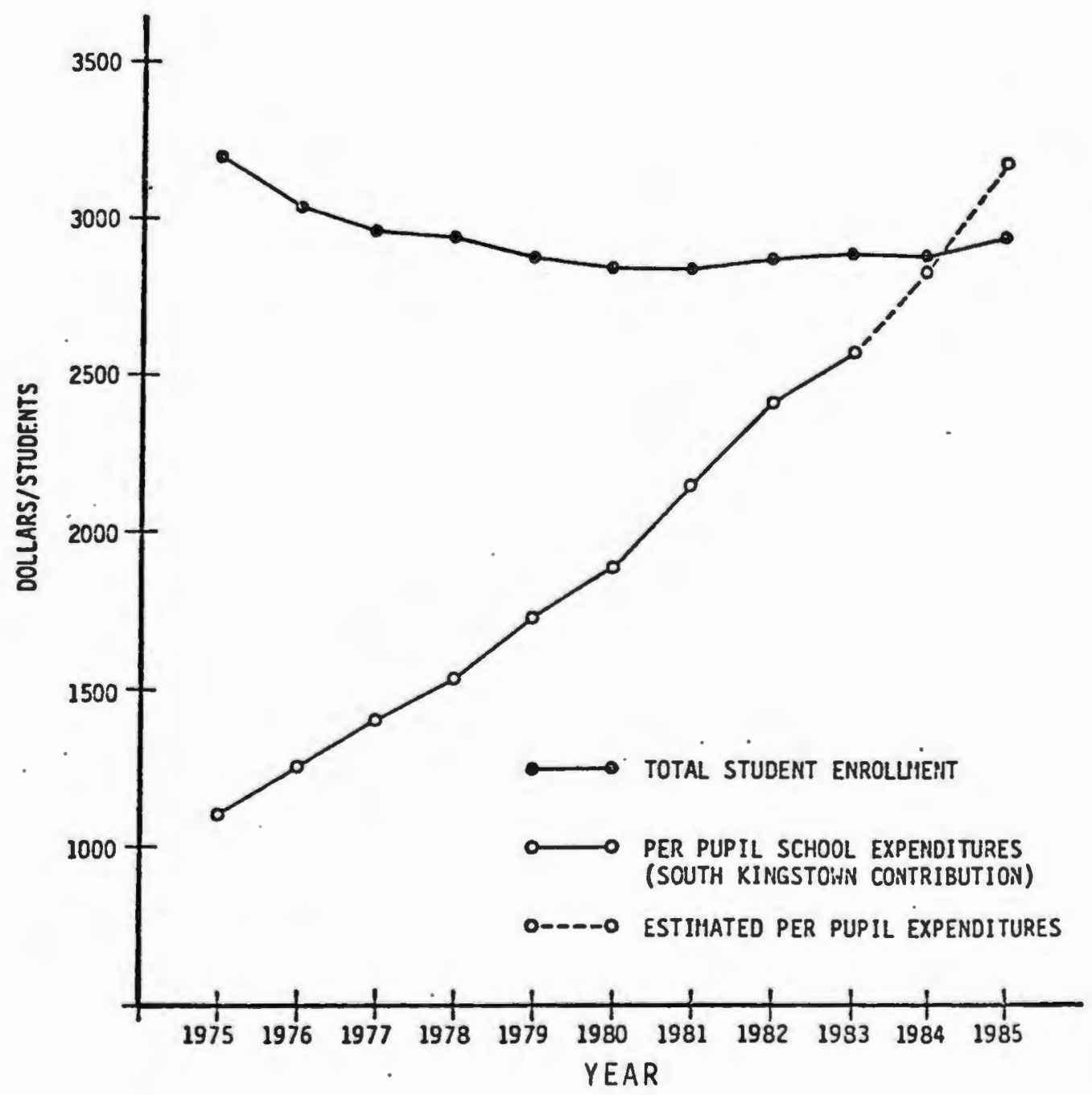

SOURCE: Preliminary Comprehensive Plan, Wilbur Smith Associates, 1985. 
the total per pupil expenditure.

As traditional sources of revenue dwindle, the Town of South Kingstown must find ways of generating more revenue locally. The recent federal policies deny financial responsibility for many locally-provided facilities and services, including schools. With federal cutbacks to both state and local agencies and projects, South Kingstown is forced to rely much more heavily on its local revenue sources, primarily its property tax. Yet the 5.5 percent cap on the local tax levy makes this task impossible. And as these traditional funds become unreliable, South Kingstown faces definite overcrowding in its school system due to the dramatic population increases over the last five years. The question then arises as to the possibility of imposing impact fees for the expansion of the school system on new residential development. The next chapter reviews this question within a legal context. 
CHAPTER FOUR

\section{THE LEGAL ISSUES REGARDING \\ IMPACT FEES}

This chapter reviews a number of issues in order to evaluate the legality and validity of imposing impact fees on new development. Further, the content of an impact fee ordinance is investigated so as to determine what is necessary for the ordinance to be upheld in court.

Impact fees evolved primarily as a means for local governments to cope with the costs attributed to new development. More specifically, those costs represent the impacts development has on existing municipal facilities and services. Impact fees are innovative in that they typically fund infrastructural needs of new development, funding not typical of traditional development requirements or fees. These take subdivision and permit exactions a step further by specifying both the purpose of the charge and the use of the resulting revenue.

Currently there exist a number of communities utilizing impact fees as a means of raising more revenue. A number of variables have contributed to the current implementation of such fees. The dominant factor rests in 
the prevalent public belief that newcomers should pay the costs associated with growth, thereby alleviating some of the fiscal stress placed on local government. Community residents as well as local government officials perceive an imbalance between benefits accrued to development from the community, and the benefits to that community gained from new development. Particularly in the case of residential development, localities are forced to supply costly public facilities and services while receiving little in return. Residential growth provides only property taxes to the local government while requiring the provision of schools, water, sewer facilities, and other basic infrastructure. In addition to the demands placed on a community's infrastructure by new development, the Rhode Island legislature recently passed the Omnibus Bill of 1985. This new legislation restricts the tax levy allowed at the local level to 5.5 percent. This aggravates the problem of providing for new development by severely limiting municipal government's options for raising revenue. Thus, impact fees appear as one of the most likely means of raising revenue available to local governments.

Recent federal policies have created a situation in which federal contributions to local facilities have decreased significantly. State agencies have had to decrease their allocations to localities also due to federal cutbacks at that level. Furthermore, future federal and 
state subsidization appear very unreliable. Thus, local governments cannot depend on the outside financial aid typical in the past and must determine alternative means of raising revenue in order to maintain and expand public facilities.

Theoretically, impact fees supply communities with the means for imposing some of the cost of new development on the new development itself. ${ }^{21}$ Practically, however, impact fees meet opposition from various sources and their imposition must be defended and justified. The legality of imposing fees on new development involves investigation from various aspects; these include a municipality's authority to impose development fees, the validity of the specific ordinance authorizing the use of impact fees, the "fairness" of the imposition of fees, and the context within which the fee is applied.

A municipal government's power to impose impact fees on new development stems from two sources: state enabling legislation ("the municipality may protect the public interest through the exercise of the police power, which it acquires as a subdivision of the state"), 22 and in some areas, local subdivision control legislation ("indeed it would seem inconsistent if a home-rule government were to enjoy less power than a non-home-rule government in the same state"). 23 
In Rhode Island municipalities are granted some authority to control and regulate land use through enabling acts in the general laws. The zoning and subdivision enabling legislations authorize local governments to control growth. These acts grant the localities "police power" over the use of land there. Section 45-22-7 of the Rhode Island General Laws (RIGL) provides that local planning boards are empowered to plan for the needs and resources of the community, including schools.

South Kingstown's subdivision regulations require that the Planning Board provide, among other things, adequate education facilities for all subdivisions. Thus even on the local level the Town of South Kingstown is required to plan and act toward providing adequate public facilities, including schools, for town residents. While the Town has a great deal of authority to control growth through land use enabling legislation and regulations, its authority to tax or exact fees is extremely limited. State authority to raise revenue in any way is specific. It outlines specifically what types of exactions are permitted and for what purpose they may be imposed in a city or town.

Ultimately South Kingstown's authority to charge an educational impact fee is implicit, not explicit. Such authority is implied in all land use regulations on both the state and local levels. Explicit authorization would exist 
only in a state law which specified the institution of an impact fee for the purpose of raising revenue toward the expansion of the public school system. An example of such an act appears in RIGL Chapter 14 entitled "Sewer Charges and User Charges." Hence, such authority to raise revenue must be explicit and specific to assure the authority to impose fees.

Typically, only those provisions explicitly approved by state legislation may be included in local ordinances. 24 But as seen in Call v. City of west Jordan, 25 the absence of an applicable enabling act does not preclude the requirement of exactions by the municipality when and if the court can imply this power from existing enabling legislation. However, although various local governments have relied upon this implied authority to impose impact fees, the danger exists that the courts will not find any authority.for such an imposition. Hence, a specific piece of legislation empowers a municipality explicitly, without implications.

As cited earlier, the predominant perception of new development--particularly residential--is that current residents should not have to bear the burden of costs specifically related to growth. Rather, such costs should revert back to the development, which ultimately shifts onto new residents. Courts have determined, however, that fees related to growth "must not exceed the . . amount 
reasonably necessary to finance the system expansion." 26 In a Michigan case the state supreme court found that the revenue raised from an increase in building permit fees was grossly disproportionate to the relative costs of project approval and permit issuance, such as administrative. 27 Similarly, a New Jersey case involved a contractor whose fees were increased from an average of $\$ 18$ to $\$ 262$. He brought suit and the court agreed that while building fees for the municipality had increased dramatically, the actual cost of regulating new construction had increased very little, if at all.28 Thus, while development costs are defrayed by imposing them back onto new development, they must be applied reasonably and proportionate to the public facilities and services required by each (residential) development.

Ultimately, impact fees are an effective means of controlling growth in a community. They are instrumental in two ways: First, they raise revenue to offset municipal costs related to new development. Second, impact fees raise the actual cost of construction in a community, potentially to the point at which the growth rate slows due to expenses. When investigating what has been deemed acceptable impact fees by the courts the primary issue to address is legality of the concept of impact fees. Past ordinances that have survived the tests of validity in court have established basic guidelines for impact fee ordinance design 
and implementation. Courts typically first establish whether or not a municipality has statutory authority (authority at the state level through the general laws) to impose impact fees on development. Again, the language in the statute typically must be so specific as to authorize local governments to impose exactions on new development. Yet local ordinances have been upheld--especially in California--when state legislation merely authorizes a municipality to regulate growth. Irregardless, once some authorization has been established, the court can then analyze the validity of the fee by applying some test. The Florida case of Contractors and Builders Assoc. of Pinellas County v. City of Dunedin stands as a landmark situation in which the city ordinance for impact fees was upheld.29 While the state supreme court found portions of the ordinance inadequate, it established what is commonly known as the "Dunedin Rule." This rule set the guidelines for local governments with intentions of drafting impact fee ordinances that will withstand the scrutiny of the legal system. The rule consists of the following:

1. New development must be the direct cause for the expansion of public facilities;

2. The user fees imposed cannot exceed the amount that the local government would incur in accommodating the new users, itself;

3. The fees must be expressly earmarked and then spent on the facilities for which they were charged.

The Florida supreme Court set forth in DUNEDIN the 
criteria to be applied when evaluating impact fee ordinances in that state. The case was used as precedent for all subsequent, relative Florida cases. For example, in Hollywood Inc. v. Broward County, the court relied heavily upon DUNEDIN and found for the validity of that ordinance. 30 Thus Broward County's ordinance passed the court's test solely on the basis of the criteria established in DUNEDIN. Another set of criteria used to determine an impact fee's validity bases the decision on the municipality's regulatory authority. Hence, when an ordinance is challenged, the court determines its validity by finding: whether the municipality has the authority to act under state law, whether the municipality has properly applied this authority through the use of the ordinance, and whether the exaction or fee is constitutionally valid as a reasonable police power regulation. ${ }^{31}$ In this instance the court essentially finds the validity of an ordinance on its face, as opposed to the previous test which emphasized the issue of an ordinance as applied. Three different tests exist to determine the constitutionality of an ordinance for impact fees:

\section{The Strict Need Test}

With this type of test the court attempts to determine whether or not a particular development has justified the fees as necessary due to the influx of new residents. In other words, this is a test of "direct 
effect." In Lampton $\underline{v}$ Pinaire, the court found that an exaction is valid if it is "based on reasonably anticipated burdens (to be) caused by the development." 32

II. The Specifically and Uniquely Attributable Test This test is more restrictive than the preceeding one in its requiring that any and all benefits resulting from the fees paid by development accrue to that development. Hence, not only must the need for improvements result from new development, but the benefits of the newly acquired fees must return to the development from which the fees derived. This "special benefit" assessment was applied in the pioneer Trust case. ${ }^{33}$ The ordinance was deemed invalid because the community was unable to prove that the need for expanding the school facilities arose specifically from the proposed development. In that instance, the ordinance as applied, not on its face, was invalidated. III. The Rational Nexus Test This test seeks a rational connection between the new development and the desired fee. Essentially this test differs from the previous one in that is shifts the burden of proof onto the developer; since the degree of evidence required to validate the exercise of police power decreases, the presumption of validity increases. One of the first cases to involve the application of the rational nexus test was Jordan v. Village of Menomonee Falls. ${ }^{34}$ While some 
courts have termed it the "reasonable relationship test," 35 a rational connection between the development and the detrimental effect must be established, even if the connection is indirect.

The reasonableness of the fee imposed by a local government has played a part in the aforementioned tests of ordinance validity. Basically a reasonable fee is one which requires development to pay only for its equitable portion of capital costs in relation to the benefits it would receive. Local governments should try, therefore, to design a fee schedule which equalizes the relative financial burdens of all properties in the community. Often, however, the. court does not get as far as "equitable portion." In the case of Lafferty $v$. Payson City, the fees collected were deposited in the general fund. ${ }^{36}$ The court in that case concluded that the fee being charged was illegal because it was not restricted to improving any specific facility affected by the development which made the payment. The courts essentially delineate the legality of an impact fee and of an ordinance by identifying acceptable characteristics and by creating tests of validity. Similarly, the courts have invalidated fees and ordinances based on various elements in either the context of the situation or the content of the ordinance. The elements form four categories: lack of statutory authority, discrimination against new residents, the fee being applied 
as a tax, and specific attribution of burden.

A number of cases in different states have shown that the courts look unkindly on fees imposed without proper legislative authorization. For example, in an Arizona case the court found that "the power of taxation is to be exercised by the state Legislature and not by municipalities, unless the power is conferred SPECIFICALLY by the charter or delegated by statute."37 While this 1973 decision suggests that the courts require specific statutory authorization of local imposition of fees, a Michigan court in 1959 stated that the local government is responsible for sustaining new development with monies from its general fund, not "on.a basis under the guise of regulating such matters as plumbing and wiring in the new houses."38 ultimately the court held that a regulation designed to raise revenue was invalid under a locality's regulatory powers.

The level of statutory specificity necessary to validate an ordinance varies from region to region, from state to state. State enabling acts imply that municipal governments may impose fees and taxes under land use regulatory law. Yet unless specifically authorized, the exaction of impact fees is not explicitly allowed at the state or local level.

Throughout the various cases involving impact fees, of the recurrent concerns of the courts was the fairness or 
equity of the fees in regard to new residents. The Utah Supreme Court requires uniformity among the classes whenever a tax or fee was imposed. This uniformity requirement was violated in Weber Basin Home Builders Assoc. v. Roy City. 39 In its judgement the court stated that the impact fee in question placed a "disproportionate and unfair burden on the class of new households." Similarly, in a Florida case, the court found that an impact tax for the expansion of the public park system "subjected new residents to double taxation due to the property tax also assessed."40 Essentially, impact fees can control residential growth by raising the cost of new development to the point at which growth is slowed, or less-desirable development (for example low-income housing) is excluded. 41 Furthermore, whether or not new development is paying for infrastructural improvements which accrue to the entire community emerges as a major concern when the courts examine the equity of an impact fee.

The question as to the nature of the charge--in other words, is it a tax or a fee--is related to the above concern with equity. "A tax is an involuntary charge for the purpose of raising revenue where the payor receives no specific good or service in the exchange for payment." 42 Thus in the case between Broward County and Janis Development Co., 43 the court struck down the "land use fee" calculated per dwelling unit. The fee was an "unauthorized 
tax" since its purpose was to raise revenue. The projected revenue far exceeded the regulatory costs for the community and was therefore invalidated. The court stated that "the amount of the fee is not equitable with land allocation - . The fee here is simply an exaction of money to be put in trust." Ultimately, while only new residents would suffer the charge, the entire community would benefit from the improvements made with the revenue.

The Pioneer Trust case displayed the court's requirement for definitive responsibility for burden or cause for expanded public facilities. The PIONEER court stated that the burden had not been proven to directly result from the new development. Thus, the requirement emerged of "specific attribution of need"; need must be specifically and uniquely attributable to the project in question.

In PIONEER, the municipality did not prove that the expansion of the school facility was solely caused by the developer's project. Rather, the developer showed that the system was near capacity without the projected school enrollment increase from his project. Thus the need for expansion existed before his development ever was proposed. Although it was within the power of the local government to require land donation (in lieu of a fee), the need for school expansion could not be specifically attributed to 
that proposed residential development.

As traditional revenue sources dwindle, local government officials are faced with major deficits and problems dealing with facility improvement needs. Many state legislatures are instituting caps on property tax levies; state aid often is based on a locality's "need"; and federal funding is unpredictable at best. The impact fee is an effective device to impose the cost of new development on the development itself. ${ }^{44}$

Politicians generally find impact fees an attractive means for raising revenue since the constituents oppose policies for increased property taxes, as well as the overall perception toward the strains new development and residents place on public infrastructure. It is socially desirable to shift the cost of new development onto the responsible parties, particularly when the need for facility expansion arises from those developments and the benefits accrue to them.

South Kingstown recently imposed its first impact fee, as described in the next chapter. Rhode Island enabling legislation, however, does not explicitly authorize such a fee; it simply allows for the control of growth and the general police power of a municipal government regarding land use. In this case the developer agreed to pay the educational impact fee to aid the Town in accommodating the new residents. 
The officials in South Kingstown currently are seeking to get a piece of legislation passed by the state Legislature. This bill (86-H8328) outlines the duties of the local planning board. Included in these duties is to study the provision of public facilities in the Town, including schools. Of key importance, however, is the granted authority to and requirement of the board to advise the town council in regard to the impact of proposed subdivisions "in order to ensure adequate public facilities," including schools. Stipulated within the act is the requirement that all dedications, fees and regulations "be reasonably related to the subdivision or other development under consideration," and be "based upon the projected costs of comparable projects." Finally, any of the funds and land dedications must be used to "mitigate the impact upon the physical, economic and social growth and development of the municipality reasonably attributable to the project."

As evidenced in the aforementioned requirements, the Town of South kingstown referred to other legislation as models for this act. The act requires both "uniquely attributable" impacts and benefits and the "rational nexus" between new development and the imposed fee, as seen in $\underline{\text { Pioneer }}$ Trust and Jordan $\mathrm{v}$. Menomonee Falls, respectively. Furthermore, the Dunedin requirement appears in South 
Kingstown's proposed act by the direct use of funds for the mitigation of a specific impact new development has on a specific public facility or service.

South Kingstown has been a forerunner in its innovative local regulations as well as its planning practices. Its desire to capture funds lost through the dissolution of traditional revenue sources stands as another innovative attempt on the part of the Town to control growth and properly provide the necessary public facilities. 
CHAPTER FIVE

CASE STUDY

This chapter describes the characteristics, both positive and negative, of the Sweet Allen Farm residential development in South Kingstown. The impacts of the development on the Town are discerned along with the fees assessed to the development. Finally, an evaluation of the effect of the fee on the development and an assessment of the "success" of the fee for the Town are included.

Sweet Allen Farm includes a large tract of land located in the Town of South Kingstown. Specifically, it is located between Curtis Corner Road, South Road and Allen Avenue in Wakefield.

In November of 1985 Twombly Developments Limited presented a proposal to the South Kingstown Planning Board. The proposal consisted of a residential cluster subdivision, a drastic alteration of the conventional subdivision initially proposed for the property in 1980. According to data revealed in the Twombly report, the more innovative cluster development design is more favorable to both the developer and the Town than the classic subdivision "cookie cutter" design. It allows varying housing densities to be 
located within proximity to each other. The design promotes the preservation of open space by "clustering" the units on smaller lots permitted by South Kingstown's Residential Cluster portion of the zoning ordinance, trading some of the private open space for larger tracts of common open space. Finally, this particular cluster development proposed phased construction in an attempt to minimize at any given phase a variety of impacts to the Town, including resident population, school population and infrastructural requirements.

Twombly proposes to develop 98 single family units (sfu) on individual lots with a minimum size of 10,000 square feet (sf). Ninety multi-family units (mfu) are planned with each building of 6 units located on $40,000 \mathrm{sf}$ lots. Finally, one duplex of two units will be constructed on a lot of $20,000 \mathrm{sf}$. By the end of the eight years planned for development, a total of 190 units on 114 lots will be completed. The phasing is as follows:

Phase I: (1986-88) Cumulative Units

$$
\begin{array}{r}
\text { SFU }-58 \\
\text { MFU }-48 \\
\text { Total }-106 \\
\text { II: } \quad(1989- \\
\text { SFU - } 27 \\
\text { MFU - 42 } \\
\text { DU - } 2 \\
\text { Total - } 71
\end{array}
$$$$
106
$$

Phase II: $\quad(1989-90)$ 
Phase III: (1991-93)

$$
\mathrm{SFU}-13
$$

Cumulative Units

190

This phasing plan has been proposed for a number of reasons. First and foremost, phasing eases the impacts of the development on the Town's budget and infrastructure. More specifically, the South Road Elementary School, which currently is at capacity, will be affected less severely with the phased development in the sense that the total impact will not be felt all at once. This phasing allows the Town time to plan for the expansion. Secondly, the phasing is the main component of a very comprehensive eightyear plan which also includes roadway construction and open space conservation. Approximately thirty acres of open space are planned for the perimeter buffer, according to Twombly's report. Twenty additional acres appear in several internal open space areas. Basically the phasing best allows the Town to cope with the impacts of the sweet Allen Farm development and helps promote the preservation of South Kingstown's quality of life.

Access to the development will be at three points: South Road, Allen Avenue, and Curtis Corner Road. The internal street system for the development was planned to achieve an equal distribution of traffic onto the existing roads. (Please refer to the attached site plan for further description of the project). Table 8 delineates the proposed linear footage of road assessed with the 
development.

On April 14, 1986 the South Kingstown Planning Board and Twombly Developments Limited fell into an agreement which consisted of a variety of elements. Twombly agreed to pay $\$ 10,000$ to mitigate some of the traffic impact created by his development. This $\$ 10,000$ amount was estimated by the Town's Public Works Director to cover costs associated with improvements to Allen Avenue near the subdivision. These improvements were noted as being partially necessitated by the Sweet Allen Farm project.

The second element of the agreement between the developer and the Town was an education impact fee determined by the Town Planner and a private planning consultant hired to establish an impact fee schedule for school expansion necessitated by residential growth. The fee of $\$ 900$ per unit was imposed based upon a construction cost per student for a new school facility. Using a middle school being built elsewhere in the state as a model, the planners derived the $\$ 900$ figure as follows: the school is built to accommodate 750 students--equivalent to South Kingstown grades 4,5 and 6 population--with 135,000 square feet. Using a multiplier of $\$ 100$ per square foot for construction, the total cost of the school is projected at $\$ 13,500,000$. The assumption is made that the life span of the school is 20 years, thus accommodating a total of 15,000 


\section{TABLE 8}

LINEAR FEET OF STREETS IN PHASING, SWEET ALLEN FARM

\begin{tabular}{lclc}
\hline Total & $\begin{array}{l}\text { Linear } \\
\text { Number } \\
\text { Units }\end{array}$ & $\begin{array}{l}\text { Feet of } \\
\text { Streets }\end{array}$ & $\begin{array}{c}\text { Time Period } \\
\text { (Years) }\end{array}$ \\
\hline I & 106 & 4650 & $1986-88(3)$ \\
II & 71 & 2200 & $1989-90(2)$ \\
III & 13 & 1200 & $1991-93(3)$
\end{tabular}

SOURCE: Twombly Developments Limited. 
students. Therefore, the cost of construction per student is $\$ 900$. The calculations are outlined below:

$$
\begin{aligned}
& 750 \text { students } / \text { year }=135,000 \text { sf } \\
& \$ 100 / \text { sf for construction }=\$ 13,500,000 \\
& 20 \text { years }=15,000 \text { students } \\
& \frac{\$ 13.5 \text { million }}{15,000}=\$ 900 / \text { student }
\end{aligned}
$$

This $\$ 900$ figure is dramatically less than the $\$ 2400$ figure derived from another formula considered. The most recent aspect of the agreement between the Town and Twombly relates to the impact made by the project's sewer pump station on the existing public sewer system. The developer has agreed to pay the fees of a private consultant to analyze and assess the impact of the development's sewer pump station on the Town's sewer system, specifically, flow projections and type of pump. Overall, Twombly Developments Limited has agreed to the basic assessments the Town of South Kingstown has made regarding the Sweet Allen Farm project's impacts on the Town. Further, Twombly has cooperated with the demands placed on him to mitigate a portion of these impacts. The developer is so cooperative basically because he wants to develop his project. The fees required do not deter him from developing in South Kingstown .

The impacts of the Sweet Allen Farm development fall into three basic categories: total population, school 
population and fiscal impact. According to the study performed by the Twombly group, the cluster development proposal is expected to produce a population of 456 by the end of the eight years planned for construction. The study used "commonly accepted housing unit population multipliers"45 and found that roughly 235 persons would be added by the 87 sfu (using a multiplier of 2.7) and 221 persons added by the $92 \mathrm{mfu}$ (with a multiplier of 2.4). This total population figure for the cluster development is 85 people less than that of the 1980 original traditional subdivision proposal.

Because of the lack of space in the existing school system, the projected increase in student enrollment is of highest priority to town officials. To project school enrollment Twombly applies the following student multipliers: three bedroom single family homes produce about 1.13 students, while two bedroom multi-family units produce roughly .15 students. The calculations show that a total of 112 students will be added to South Kingstown's school system from this development. Using past trends Twombly established that $78 \%$ of new students will be elementary-school-age, while $22 \%$ will be secondary-schoolage.

Ultimately South Road School's population will increase by 87 students from the Sweet Allen Farm project, 
while 25 students will be added to the junior and senior high schools. Table 9 delineates the phased school enrollment increases according to grade levels. It is important to note, however, that these school population increases will be occurring over time, not all at once. Therefore the phased cluster housing development will add the aforementioned student population in phases. As previously stated, the phasing of the development helps the Town deal with the fiscal and infrastructural pressures created by this development. Thus, while capital expansion will be necessary, the phasing at least partially relaxes the pressure of time.

The third category of impact made by this residential development is a fiscal one, comparing related municipal expenses and revenues. According to Anna Prager, South Kingstown's Planner, the provision of basic municipal services costs the Town $\$ 315$ per capita, excluding education. School costs equal $\$ 3197$ per pupil. Table 10 displays the net results of revenues minus expenses without the impact fees previously mentioned. As stated in the Twombly report, the full negative fiscal impact on the Town will not be realized unitl 1990 with the completion of the project. Twombly's calculations show that the development would yield a positive impact to the Town for the first two years. Yet by the end of 1988 the Town will have incurred a net impact of $-\$ 35,951$ per year. The net impacts were 
TABLE 9

ANNUAL ADDITIONS TO SCHOOL POPULATION, SWEET ALLEN FARM

\begin{tabular}{|c|c|c|c|}
\hline Year & Elementary & Secondary & Total \\
\hline $\begin{array}{l}1987 \\
1988 \\
1989 \\
1990 \\
1991 \\
1992 \\
1993\end{array}$ & $\begin{array}{r}15 \\
16 \\
13 \\
20 \\
20 \\
1 \\
1\end{array}$ & $\begin{array}{l}4 \\
5 \\
4 \\
5 \\
6 \\
1 \\
1\end{array}$ & $\begin{array}{r}19 \\
21 \\
17 \\
25 \\
26 \\
2 \\
2\end{array}$ \\
\hline Total & 87 & 25 & 112 \\
\hline
\end{tabular}

SOURCE: Twombly Developments Limited. 
TABLE 10

NET FISCAL IMPACT: 1986-1994, SWEET ALLEN FARM

\begin{tabular}{ll}
\hline Year & Result \\
\hline 1986 & $\$ \quad 1,782$ \\
1987 & 12,124 \\
1988 & $(35,951)$ \\
1989 & $(88,060)$ \\
1990 & $(144,984)$ \\
1991 & $(223,192)$ \\
1992 & $(216,737)$ \\
1993 & $(223,415)$ \\
1994 & $(223,415)$ \\
\hline
\end{tabular}

SOURCE: Twombly Developments Limited. 
calculated as follows:

\begin{tabular}{|c|c|c|c|}
\hline Year & Revenues & Expenses & Net Impact \\
\hline $\begin{array}{l}1986 \\
1987 \\
1988 \\
1989 \\
1990 \\
1991 \\
1992 \\
1993 \\
1994\end{array}$ & $\begin{array}{r}1,782 \\
109,553 \\
163,747 \\
184,255 \\
249,067 \\
292,291 \\
308,428 \\
311,433 \\
311,433\end{array}$ & $\begin{array}{c}0 \\
97,429 \\
199,698 \\
272,315 \\
394,051 \\
515,483 \\
525,165 \\
534,848 \\
534,848\end{array}$ & $\begin{array}{c}1,782 \\
12,124 \\
(35,951) \\
(88,060) \\
(144,984) \\
(223,192) \\
(216,737) \\
(223,415) \\
(223,415)\end{array}$ \\
\hline
\end{tabular}

* () delineate negative impact, or cost, to the Town.

Twombly believes that the time lapse between the project's approval and its completion should enable the Town to establish means of countering the negative impact. The aforementioned per unit impact fee is part of a solution to the infrastructural problem in South Kingstown. The $\$ 10,000$ imposed on the developer surely will carry over to the cost incurred by individual home/land buyers, and that figure converts into $\$ 52.63$ per unit imposed for road improvements. Finally, the consultant's fee of $\$ 1,000$ for studying the impacts of Twombly's sewer pump station on the municipal sewer system will add roughty $\$ 5$ to the per unit cost. Overall, the additional housing cost resulting from fees imposed by the Town amounts to nearly $\$ 958$.

When analyzing the Sweet Allen Farm development project the effect of these fees on the housing market must be considered. The figure of $\$ 958$ estimated to be added to housing/land costs seems insignificant. The median house 
value in 1980 , as cited earlier, was $\$ 54,900$ in South Kingstown. The additional costs resulting from impact fees imposed by the Town amount to roughly $.17 \%$ of the median cost of a home in 1980. With the 1983 revaluation in South Kingstown, housing values increased significantly. Therefore the $\$ 958$ estimate amounts to an even smaller percentage of the cost of a home in the Town. The effect of the impact fee on the housing market, then, is incidental. The fees cannot constitute "elitist zoning" in this case, an accusation commonly made regarding the general imposition of impact fees.

The housing market has been characterized as tight for South Kingstown. The added thousand dollars of impact fees, however, will not affect the buying potential of a new resident. Finally, if impact fees are not collected, the Town will have to determine alternatives for raising revenue, in order to adjust to rapid growth. Thus, the cost to the home buyer will be the same in the long run.

Since the fees' effect on the development itself are minimal, the next consideration is the benefit accrued to the Town regarding the revenue raised from impact fees. The $\$ 10,000$ are not included in this analysis because they simply reimburse the Town for existing debts from road improvements. In fact, it has been questioned whether the $\$ 10,000$ paid by the developer will actually cover the total 
cost of road construction to the particular portion of Allen Avenue. If the improvements cost more than $\$ 10,000$, the developer will not be required to subsidize the difference. Rather the Town will be forced to fund the outstanding amount. For this analysis, therefore, only the $\$ 900$ per unit impact fee is included. Two scenarios have been developed to discern the actual benefits to the Town resulting from the development--more specifically, from the newly acquired $\$ 900$ per unit.

\section{Best Case}

The most positive, and hence profitable, scenario for South Kingstown describes a situation in which expansion of South Road Elementary School becomes necessary after all of the 190 residential units are built. In this situation the $\$ 900$ impact fee collected from each unit yields a total revenue figure of $\$ 171,000$ not including the interest that will accrue over the eight years.

Assuming the student population projections are accurate, the 112 students added to the system will necessitate expansions of South Road School and possibly the junior high school. Construction costs, using the model referred to earlier, will equal roughly $\$ 13.5 \mathrm{million}$. The revenue-plus-interest raised from impact fees hardly affect the expenses required to accommodate the new student population. And although impact fees are imposed solely to 
mitigate construction and other capital expenses, it is important to realize that additional students require additional operating costs as well. At a cost of $\$ 3197$ per student, the total public school operating cost resulting from just the Sweet Allen Farm development amounts to $\$ 358,064$.

Operating costs typically are paid from the Town's general fund. Yet the net impacts previously outlined show the negative fiscal effects of the development. Thus even in the best case scenario, the Town of South Kingstown faces overwhelming costs and debts specifically resulting from the Sweet Allen Farm development.

II. Worst Case

In the worst case scenario the Town of South Kingstown is forced to expand its school facility after the first residential unit has been consțucted. As a result, only the first $\$ 900$ will have been collected and no "school expansion fund" will have been established yet. If this situation arose the Town would be forced to float a bond or borrow money against future revenue generated by the sweet Allen Farm development in order to facilitate the additional students. Unfortunately immediate expansion of South Road School necessitated by the student(s) added by one residential unit in the project will not be cost effective until much in the future, when roughly 25 students are added 
to the school's enrollment list.

Ultimately the cost per pupil for the Town will be substantially higher in the worst case scenario than currently quoted. Assuming the cost of a new classroom would be roughly $\$ 60,000$, the 1.13 school-age children from the first home will be costing the Town $\$ 53,097$. Yet the Town will have received merely $\$ 900--l e a v i n g$ a difference of $\$ 52,197$.

It has already been established that the cost per pupil for the Town far exceeds the impact fee. But in addition, the capital expenditures and improvements necessitated by residential growth place substantial pressures on the Town's financial status. A bond would be necessary in any situation to fund school-related capital improvements. The impact fee revenue would be used to pay back the loan. Obviously, however, the $\$ 900$ assessed to each unit makes nearly no dent in the ultimate expense associated with school expansion. Why, then, is the impact fee so low? When interviewed the Town Planner revealed that any fee imposed will have to be substantiated and justified in the end. She and the Town believed that the lower assessment of $\$ 900$ is more justifiable than the $\$ 2400$ figure which results from another calculation. (Please refer to the Appendix supplement). And while acknowledging the deficiency in the fee regarding the cost of capital improvement, Ms. Prager stated that the revenue generated 
from the impact fees will help finance the improvements. In a word, the current impact fee schedule is a beginning. 
CHAPTER SIX

CONCLUSIONS

As evidenced in the scenario described before, the education impact fee imposed in South Kingstown falls short of generating a significant amount of revenue for the Town. Communities in other states, however, have imposed impact fees in the past, and will continue to do so. The intention behind imposing a development fee varies from community to community. There exist three basic reasons a local government imposes an impact fee: to increase general revenue specifically allocated for capital expenditures, to shift the cost of new development back onto new residents, and to deter future, typically residential, growth.

\section{Increase General Revenue}

\section{for Capital Expansion}

Communities often assess a fee on new development for the purpose of increasing their general fund and therefore increasing allocations to capital improvement. In these instances, the impact fee is posing as a substitute for some other, additional tax. As federal aid to local and state governments decreases at an increasing rate, municipalities are forced to rely more heavily on local 
revenue-raising means, in other words, property tax. Yet in Rhode Island, the Omnibus Recovery Act limits communities' ability to tax property by placing a $5.5 \%$ cap on either the tax levy or the rate. Impact fees, therefore, are an effective means of capturing funds lost through the tax limitation, and increasing the local general budget. Yet imposing fees to replace federal and state aid can prove to be unrealistic. The South Kingstown example shows the necessity to defend any tax or fee imposed. Thus, the Town assessed a nominal impact fee on the Twombly residential project in order to avoid conflict and resistance on the part of the developer. To aggravate the situation, the voluntary nature of the impact fee payment by the Sweet Allen Farm project limits the Town's freedom in charging the development. Finally, after calculating rough education-related costs to the Town generated from sweet Allen Farm, the fee imposed appears grossly nonproductive and ineffective. The $\$ 900$ assessed to each residential unit creates an insignificant benefit to the Town.

II. Shift New Development

Costs to New Residents

As described in an earlier portion of this thesis, the public concept of making new development pay its own way in a community is common. As a community grows, its infrastructure is forced to accommodate a larger 
population, and therefore must grow proportionally with the population. Impact fees can be viewed, therefore, as an admission fee into the community or as a means of buying into the existing (school) system. Current town residents have financially supported the infrastructure in the community in the past and present. An appropriate proportion of the cost of maintaining and expanding local facilities is assessed to new development in an attempt to make newcomers share in the financing of capital improvement.

Thus, local residents are not forced to subsidize the expense of expanding the system due to new development. Rather new residents pay their own way in the community. Again the South Kingstown example seems to fall short of achieving this goal. The fee imposed on each unit insignificantly affects the ultimate cost to the Town for providing adequate school facilities. Therefore the education impact fee does not "make development pay its way" in this case. It should be noted, however, that the developer intends to phase the development over a period of eight years in an attempt to allow the Town to plan for the impacts created by the Sweet Allen Farm development. But ultimately, the project will not be paying for its use of education facilities in South Kingstown. 


\section{Deter Growth}

A third reason for imposing impact fees relates to the impact of the fees on new development itself. When used as a growth deterrent, an impact fee is viewed by potential developers and residents as a financial burden. Many times neighboring cities and towns do not impose development fees, and the community in question becomes even more unattractive to potential newcomers. Thus, the impact fee actually deters development and slows growth in a community. As described in the previous chapter, the effects of the education impact fee on South Kingstown's housing market are non-existent. Because of the need to substantiate and defend the fee, the added housing costs which result are nominal and do not affect newcomers' ability to purchase a home in South Kingstown or in the Sweet Allen Farm development. Hence, the $\$ 900$ impact fee imposed by South Kingstown does not satisfy the goal of deterring residential growth.

Because the South Kingstown scenario does not achieve any of the aforementioned objectives related with impact fees, a number of alternatives exist:
A. Substantially increase the fee imposed.
B. Transform the existing fee into a sales tax on houses.
C. Tax the developer on the full value of the property. 


\section{A. Increase the Fee}

The existing impact fee in South Kingstown is intended to fund some of the school expansion necessitated by residential growth. Yet, as described earlier, the $\$ 900$ assessment hardly alleviates the grave expense incurred by the Town. Therefore one alternative is to increase the fee imposed on new development. The City of woonsocket recently imposed an education impact fee on residential developments. The fee was established based on the cost of relative capital expenditures over the next 20 years and the projected number of units over the same time period. The resulting fee is $\$ 2,372$ per unit, a substantial increase over South Kingstown's impact fee. Thus the suggestion of increasing the fee appears a valid one. However, the existing voluntary system in South Kingstown does not allow for such increases.

Specifically, within written legal agreements between the Town and Twombly it is stated that the $\$ 900$ estimate cannot be increased, but rather the developer will be reimbursed should the Town decrease the fee. More generally, the existing fee has been applied to one development; future developers may contest higher fee schedules, basing their arguments on the Sweet Allen Farm fee payment. Thus the Town may encounter difficulty in the future should it decide to increase its education impact fee. And since no legislation presently exists authorizing 
the imposition of impact fees, the Town of South Kingstown would have little defense for increasing its impact fee schedule. In order to successfully increase impact fees for school expansion, South Kingstown must have explicit authority to impose such fees through enabling legislation passed at the state level.

\section{B. Tax Houses as Tangible Property}

The Town of South Kingstown taxes real and tangible (or personal) property separately and differently. Tangible property includes cars and trailers in the case of South Kingstown. It is proposed that the Town tax houses as though they were "tangible" property, imposing a one-time sales tax similar to the state's car sales tax. This proposal contains one basic advantage over impact fees: the tax would be a general revenue tax and therefore the Town would not have to define or "earmark" revenue made to a specific capital improvement project. In addition, the Town would not have to defend the amount because it would be proportionate to the value of the home. It would exist as a uniform tax over all units to be paid at the time of purchase. Thus, if a current resident moves to another house in town, he or she would pay a tax on the difference in value between the two homes.

The state very likely would desire a portion of the profit made from such a tax. For example, if the tax 
amounts to 2 percent of the value of the home, the State could receive $1 / 2$ percent, leaving $11 / 2$ percent for the Town. This proposal is very equitable because it assesses the worth of the home before imposing the charge, whereas a flat fee may be less equitable for a lower-income household. For example, 2 percent of a $\$ 100,000$ home amounts to $\$ 2,000$, to be paid by the homeowner. However, the buyer of a $\$ 50,000$ home pays $\$ 1,000$, much more manageable for the lower-income household. The flat fee is assessed to all homes, regardless of value. Therefore, the less wealthy in town pay the same fee as the more wealthy.

This tax, as all revenue-raising devices, requires explicit legal authorization from the state. And, as mentioned previously for impact fee legislation, the approval of such authority is unlikely. Rhode Island courts tend to disapprove of extending municipalities' ability to tax or charge their citizens. Additional local taxes basically amount to revenue lost at the state level. This is why the collaboration between the state and town was introduced earlier. Thus the state would benefit from South Kingstown's home sales tax and would be more likely to pass the appropriate legislation. 


\section{Tax the Full Value of the Developer's property}

The third alternative to the existing education impact fee is to tax unfinished homes as though they were complete. Currently the tax assessor visits all incomplete home sites at the end of each year and assesses their value according to their stage in development. This alternative proposes that homes which are roughly 80 or 90 percent completed be assessed as substantially completed dwellings. The current practice in South Kingstown of assessing unfinished homes at a rate 20 to 30 percent less than the standard rate costs the town a relatively significant amount of funds annually.

By applying the "completed" standard rate on homes 80 to 90 percent finished, the Town would raise roughly the same amount of money as the impact fee currently imposed. This figure is low when considering the actual cost of capital improvements. But the revenue could go directly into the general fund to be applied as town officials deem necessary. This alternative does not require enabling legislation--a definite advantage over the previous two alternatives. The tax assessor already has the authority to assess property's value and to tax accordingly. Thus he needs no additional authorization to tax 80 percent completed homes as 100 percent complete. This alternative would not raise a substantial amount of revenue for the 
town, however, and should not be considered as a replacement for impact fees.

The South Kingstown scenario is very telling of the effects associated with impact fees. The education impact fee imposed on Sweet Allen Farms does not accomplish any of the three goals associated with impact fees. Why, then did the Town continue with its plans to charge such a fee?

As described earlier in this thesis, South Kingstown has continuously enacted innovative planning policies and practices. The introduction of impact fees in the Town appeared as an introduction of such fees in the state as well. Only recently did the City of woonsocket impose a similar fee. Excluding these two communities, impact fees do not exist in the State of Rhode Island. Ultimately the South Kingstown governmental body chose to slowly familiarize citizens, developers and newcomers with the concept of impact fees.

The Town Planner believes that future fee schedules will include more significant charges, once the basic precept has been acknowledged as valid and accepted by the courts and the citizenry. Further, the Town Solicitor stated that because no legislation currently exists which explicitly authorizes the imposition of impact fees at the local level, officials were forced to establish an agreeable fee schedule for both the Town and the developer. Had the Town assessed a significantly higher charge onto the Sweet 


\begin{abstract}
Allen Farm project, the developer may have contested payment, and ultimately sued the Town. Thus, South Kingstown officials very much were dependent upon the cooperation of the developer when establishing an appropriate impact fee schedule for public school expansion. Mr. Steve Alfred, South Kingstown Town Manager, is wary of viewing the impact fee as a panacea to the problem of school overcrowding and uncontrolled residential growth. It is important to realize that the concept of impact fees represents a limited solution to the education problem, according to Alfred. Thus, impact fees exist as one component in a more comprehensive local solution.
\end{abstract}


CHAPTER SEVEN

RECOMMENDATIONS

The preceeding chapter drew a number of conclusions from the research conducted regarding the imposition of impact fees. The degree of success was determined for South Kingstown's application of an education impact fee to sweet Allen Farm, a proposed residential cluster development in the Town. Finally, three basic alternatives to the fee imposed were described and critiqued. This chapter goes further; it delineates comprehensive solutions to the problem of providing adequate school facilities in a town experiencing dramatic residential growth. The first section discusses modifications relating to impact fees on.ly. 'The second portion of the chapter identifies problems and suggests solutions regarding South Kingstown's school system.

\section{Impact Fees}

Impact fees can be an effective means of raising revenue for a municipality. Most local governments are losing vast amounts of revenue from federal and state sources and local taxes are insufficient for maintaining and expanding public facilities. Thus, impact fees aid a city 
or town in financing capital improvements and expansion. In south Kingstown the only impact fee currently is imposed for education facility expansion. Unfortunately the fee--\$900 per housing unit--is ineffective and does not achieve any of the objectives previously outlined. The charge is too low to mitigate any of the impact on the Town that will be created by the residential development. As described earlier, the fee was agreed upon by the Town and the developer, and will be paid voluntarily as no legislation requiring such payment currently exists. Therefore an inexpensive fee schedule was designed with the notion that this fee would be the forerunner of future fees in the Town.

In order for an impact fee to be applied with any security of its validity, enabling legislation authorizing a municipality to impose such a fee must exist. South Kingstown currently has a piece of legislation awaiting approval in the state legislature. Without this legislation the Town may be forced to engage in agreements similar to that made with Twombly Developments Limited. This voluntary payment situation hinders the success of the impact fee because it limits the amount imposed on a development. And while the Town can impose impact fees without authorization, the possibility always would exist that the fee could be contested and the Town taken to court. Thus the Town should 
continue to rally for state acceptance of enabling legislation allowing the imposition of impact fees. The public should be more actively involved. Public education of the issues involved as well as public participation in rallying for state support would improve the Town's chances of getting the bill passed by the state legislature. Once the Town had explicit authority to impose impact fees it could impose a more effective--in other words higher--fee. The Town of South Kingstown recently imposed its first impact fee. Because of the risk involved in charging such a fee without explicit legal authority or precedent the Town assessed the residential development in question a conservative fee, one which proved insufficient in alleviating the financial burden resulting from the development.

As stated earlier in the text, the current impact fee is merely the forerunner to future, more effective fees. The Town has at its disposal a valuable tool for creating revenue, thus easing the strain of providing basic public facilities to its residents, current and future. Once comfortable with the fee schedule technique, the Town must consider increasing the existing education impact fee as well as introducing additional impact fees, for such facilities as sewer, water and road expansion. Furthermore, existing impact fee schedules in other states should be used as models. For example, in Dunedin, Florida, the impact fee 
is based on the number of bedrooms in a unit rather than being a flat fee imposed on all types of housing units. (In the case of Sweet Allen Farm in South Kingstown, single family homes with three bedrooms as well as the multi-family units with two bedrooms are all being charged the $\$ 900$ impact fee for school expansion).

Impact fee ordinances across the country have included such basic publically-provided facilities as police and fire protection, sewer connection, public water provision, road expansion, school expansion and library facilities and privileges. Eventually South Kingstown should consider employing these tactics in order to mitigate some of the infrastructural pressures created by new-primarily residential--development.

Town officials obviously are investigating new means of raising revenue in order to maintain and expand public facilities. Impact fees remain as one tool, with advantages and disadvantages, for capturing funds lost through federal and state budget cuts. Various taxes exist which could, in coordination with impact fees, increase local general funds. As described in the previous chapter, South Kingstown should consider taxes such as home sales tax as ways to increase its annual revenue. The transfer development tax is another example of the innovative yet realistic techniques utilized by other communities as revenue raisers. 
The Town has three basic hurdles to cross regarding the use of additional taxes. First, state enabling legislation is necessary for each type of tax imposed on the local level. Passage of legislation authorizing additional revenue raised by local governments is rare, and the state typically wants some portion of the profit made from the tax in question. Second, the officials in the Town ultimately creating such tax policies remain politicians, with constituencies and reelections, and policies involving additional taxes are unattractive to the voting population. Thus, town officials can be limited in the policies. they pass by the political system within which they work. Third, any social system shows a strong tendency toward inertia, a resistance to change. The two taxes mentioned are relatively innovative. The concept of introducing new taxes in South Kingstown may meet with great opposition from residents and other town offlcials. Yet in order to provide the public services and facilities considered basic in the Town, additional revenue is necessary.

Ultimately the Town would float a bond or employ some other means of obtaining funds, means which eventually rely on citizens' dollars. Thus, current and new residents will have to invest in capital improvements in South Kingstown, whether sooner or later depends upon the means employed by the Town. 


\section{The School System}

Chapter Three in this thesis investigated the

various characteristics of the Town of South Kingstown which led to the Town's need to find alternative means of raising revenue. The Town's school system includes six elementary schools located across the Town. Because of the land area in South Kingstown, its schools are spread out at great distances from each other. In addition, each area in Town desired a smaller "neighborhood" school for its school children. This accounts for the proportionally large number of elementary schools serving the same grades in South Kingstown. But as particular areas' populations increase, these neighborhood schools become insufficient in accommodating the school-age population.

The Town Council appointed a task force to study the present school system and to determine a number of possible solutions to the problem of overcrowding in the elementary schools. According to the preliminary report submitted to the Council April 21, 1986 the following conditions exist in the South Kingstown school system:

1. All elementary schools have either reached or will soon exceed their design capacity, (design capacity refers to the number of classrooms in a school and the standard number of children allowed per classroom);

2. Elementary school enrollments are projected to rise for at least the next five years; 
3. Current elementary school crowding will carry over to the junior and senior high schools by the year 1990;

4. Sufficient space for special programs including testing, counseling and tutoring, does not exist in the schools. In fact, use of corridors and storage rooms and dual use of offices occurs on a daily basis in all the schools.

All the options identified by the task force included expansion or new construction or both. Further, a number of the options proposed the creation of an "intermediate" grade, including grades 4 through 6 , to be housed in separate schools, rather than remain with grades $k$ through 3 .

The underlying problem in South Kingstown regarding elementary school overcrowding is the districting policies and basic organization of schools and school enrollment distribution. Some schools have been forced to utilize their cafeterias as classrooms, while others have space for additional children. This imbalance exists because of the misconception that the primary schools in South Kingstown service neighborhoods or specific areas. The Town's expanse and growth have made these schools' locations actual handicaps to providing enough space for school-age children. Redistricting would rectify most of the problems associated with the neighborhood school concept. The entire 
system would be more manageable because of the flexibility that would result. If the school department decided to house certain grades in separate school buildings, this would make the system even more manageable. School expansion would be more controlled and purposeful because population increases in particular age categories would be accommodated in one or two schools rather than six. Thus, the school facilities would be able to adjust more easily to the school enrollment "bulges" which pass through the system.

Again the problem of resisting change appears regarding the possible redistricting of schools in South Kingstown. A report was made in 1971 recommending redistributing the school children in the public school system to better accommodate the population peaks. Parents resisted this proposal so adamantly that the entire study was disregarded in the end. The reaction to the 1986 report is still unknown. Researchers are hopeful that parents will be more open to such a change in the school system now because the overcrowding problem is more significant than 15 years ago.

The problem of providing adequate education at the local level is becoming more and more severe in the Town of South Kingstown. Development pressures have been coupled with decreasing federal and state aid, as well as stateimposed taxing limitations in forcing town officials to 
determine new ways of raising revenue. Impact fees are a viable way of capturing some of the lost revenue as well as increasing general revenue in a municipality. Yet the underlying problem within a system, should a problem exist, must be identified and resolved simultaneously with the new policy or techinque.

This thesis reviewed the legal validity and

financial success of imposing impact fees. More specifically, it described the pressures and impacts created by residential growth in South Kingstown, affecting the public school system. This study has shown impact fees can be effective in alleviating some of the financial burden experienced by the Town. It has also proved that an impact fee schedule must be established based on actual cost to the Town and population generated by a particular development. The challenge of providing necessary services and facilities intensifies as federal policy leans further and further away from state and local intervention and aid. Local governments across the country are investigating alternative means of raising revenue in order to accommodate growth. South kingstown, as a rapidly growing community, has as its primary problem the cost of maintaining and expanding its school system in accordance with the population increases. Thus its officials have employed education impact fees in an attempt to raise sufficient 
revenue to mitigate the impact new residential development makes on the Town's school system. This fee was the first imposed in the Town of South Kingstown and one of the first in Rhode Island. Its ultimate success is yet to be seen. 


\section{FOOTNOTES}

125.

${ }^{1}$ E.G. Hoachlander, "Financing Public Education," p.

2 For example, Florida Constitution Article VII Section 9; Proposition 13, Calfiornia Constitution Article 13a; R.I. Omnibus Bill, Chapter 182, \#5671, RIGL.

${ }^{3}$ P.C. Coughlan, "Financing Alternatives to Local Governments," p. 150.

${ }^{4}$ Newport Building Corp. v. City of Santa Ana, 210 Cal.App. 2d 771, 775-6, 1962.

${ }^{5}$ City of Dunedin v. Contractors and Builders Assn. of Pinellas county, 358 so. $2 \mathrm{~d} 846,1978$.

${ }^{6}$ For example, Home Builders and Contractors Assn. of Palm Beach County, Inc. vo Palm Beach County, 8 Fla. Wkly. 2515, 1983; and Hollywood, Inc. vo Broward County, 431 So. $2 d 606,1983$.

${ }^{7}$ Pioneer Trust and Savings Bank v. Village of Mount Prospect, $\frac{12 \mathrm{IIl}}{22} \frac{\mathrm{d} 375,176 \mathrm{NE} 2 \mathrm{~d} 799}{1961 .}$

${ }^{8}$ Patterson v. Alpine City, 663 P. 2d 95, Utah, 1983.

${ }^{9}$ Projections of Education Statistics to 1990-91,

National Center for Education statistics, volume $I_{\text {, }}$

Washington, D.C., March 1982, p. 3.

${ }^{10}$ Ibid., p. 2.

${ }^{11}$ Population Characteristics, U.S. Bureau of the Census, washington, D.C., 1983. All subsequent statistical figures were derived from the U.S. Census.

${ }^{12}$ R.I. Basic Economic Statistics: 1985-6, R.I. Department of Economic Development, Providence, R.I., June 1985 , p. 119.

13 Annual State Report on Local Government Finances and Tax Equalization, R.I. Department of Community Affairs, 
Providence, R.I., 1984, pp. 10-11.

14 Frank Ansuini, Inc. v. City 으 Cranston, 264 A. $2 \mathrm{~d}$ 910, R.I., 1970, p. 71 .

$$
\begin{aligned}
& 15_{\text {Ibid., p. }} 71 . \\
& 16_{\text {Ibid., p. }} 71 .
\end{aligned}
$$

${ }^{17}$ Preliminary South Kingstown Comprehensive Plan, Wilbur Smith Associates, 1985-6, p. 38.

$$
18 \text { Ibid., p. } 34 \text {. }
$$

19 Annual State Report on Local Government Finances and Tax Equalization, R.I. Department of Community Affairs, Providence, R.I., 1984, p. 11.

$$
\begin{aligned}
& 20 \text { Ibid., p. } 11 . \\
& 21 \text { Fred Jacobsen and Jeff Redding, "Making }
\end{aligned}
$$

Development Pay Its Way," in North Carolina Law Review, Vol. 55, March 1977, p. 419.

22 Piper v. Meredith, 110 N.H. 291, 295, 266 A. $2 d$. $103,106,1970$.

${ }^{23}$ State and Local Government in a Federal System, D. Mandelker and D. Netsch, p. 180.

24 Hylton Enters., Inc. v. Board of Supervisors, 220 VA. 435,258 SE 2 d 577, 1979.

${ }^{25}$ Ca ll v. City of West Jordan, 606 P. 2 d 217, 219, Utah, 1979 .

${ }^{26}$ Broward County v. Janis Dev. Corp., 311 So. $2 d 371$ Fla. Dist. Ct. App., 1975.

${ }^{27}$ Nerrelli v. City of St. Clair Shore, 355 Mich. $575,586, \frac{96 \mathrm{NW} \mathrm{2d}}{14} 4,149,1959$.

${ }^{28}$ Daniels vo Borough of Mt. Pleasant, $23 \mathrm{NJ}, 357$, 129 A. 2d 265, 1957 .

${ }^{29}$ City of Dunedin v. Contractors and Builders Assn. of Pinellas County, 358 so. $2 \mathrm{~d} 846,1978$

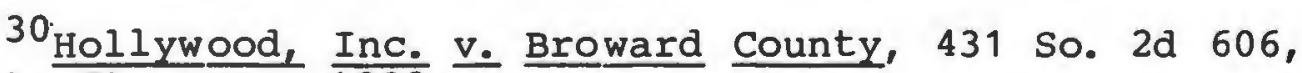
Fla. Dist. Ct. app., 1983. 
${ }^{31}$ Constitutionality of Subdivision Control Exactions: The Quest for a Rationale, R.A. Johnston, 52 Cornell L.Q. $871,873,1967$.

${ }^{32}$ Lampton v. Pinaire, 610 s.w. 2d 915 , Ky. Ct. App., 1980

${ }^{33}$ Pioneer Trust and Sav. Bank $v$. Village of Mt. Prospect, $\frac{\text { IIl. }}{22 \mathrm{~d} 375}, \frac{17}{16 \mathrm{NE}} . \frac{\mathrm{d}}{2 \mathrm{~d}} 7 \frac{\dot{99}}{1961 .}$

34 Jordan v. the Village of Menorionee Falls, 28 wis. $2 d 608,13 \overline{7 \text { N.W. }} \overline{2 d} \overline{442}, \frac{1965 .}{1965}$

${ }^{35}$ Coronade Dev. Co. v. City of McPherson, 189 Kan. $174,178, \frac{368 \text { P. } 2}{2} \frac{1}{51}, \frac{50}{54}, \frac{1}{19} 62$.

${ }^{36}$ Lafferty v. Payson City, 642 P. $2 d 376$, Utah, 1982.

${ }^{37}$ Homebuilders Assn. V. Riddel, 109 Ariz. 406, 510

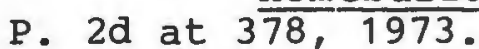

${ }^{38}$ Merrelli v. City of st. Clair shores, 355 Mich.

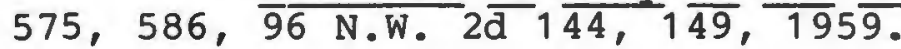

${ }^{39}$ Weber Basin Home Builders Assn. v. Roy City, 26 Utah 2d 215, 487 P. $2 \mathrm{~d} \frac{\mathrm{B}}{866}, 1971$.

${ }^{40}$ Vendito-Siravo, Inc. v. City of Hollywood, $39 \mathrm{Fla}$. Supp. 121, (Cir. Ct.), 1973 .

41 The Institute on Planning, zoning and Eminent

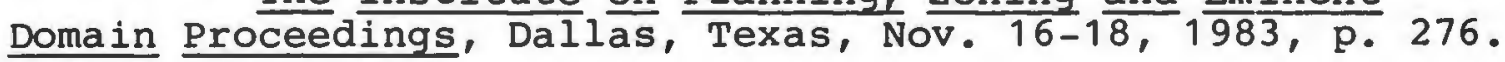
42 Ibid., p. 284.

43 Broward County v. Janis Dev. Corp., 311 So. $2 \mathrm{~d}$ 371, 375, Fla. Dist. Ct. App., 1975.

${ }^{44}$ North Carolina Law Review, p. 419.

45 The Fiscal Impact Handbook, Robert $W$. Burchell and David Listokin, Center for Urban Policy Research, New Brunswick, N.J., 1978, p. 275. 
APPENDICES 
M E MO

TOWN OF BOUTH KINGSTOWN

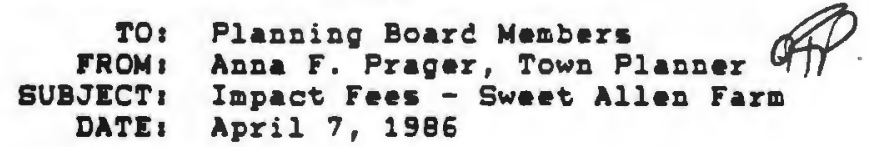

Ms. Collins uses a figure of $\$ 500$ for educational impact fees. That figure is based or a review of what fees are paid in Florida. This figure may be too low for South Kingstown. Our consultant on impact fees provided we with the following cost for school construction:

1) For an all inclusive school - including cafeteria, library, etc. - $100 /$ square foot, on the basis of 25-30 sq.ft. per student per classroom.

The maximum student count per classroom being 25 .

The cost per claseroom $-25 \times 30 \times 100=\$ 75,000$.

This figure can probably be reduced by $20 x$ since classroom additions need not be all inclusive.

$25 \times 30 \times 80=60,000$, which translates into

Cost per student $=2,400$.

This cost may not be realistic since each classroom will be used by more than one group of 25 stduents over the life span of the classroom.

2) Another option that the School Department has, is to build (i. a sew middle school - grades 4, 5 and 6 . 
Evir. of South Kingstowe

Towi Plañer

Mero - Impact Fees - Swet Alled Faru

Page 2

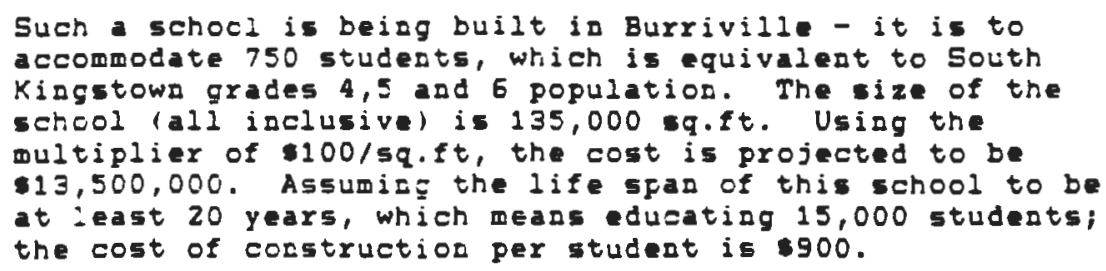

Al1 the figures discussed are based on wany assumptions. The Planaing Board will have to ia the cext wonth, refine these assumptions; at this point the cost per student range as discussed above. It is up to the Planding Board to decide what is a reasonable amount.

In conclusica, the agreemt $t$ is for educational inpact fees only, and other ixpacts should be ogotiated separately.

AFF : $\mathbb{0} 0$

Enclosure 
M E M O

TOWN OF SOUTH KINGSTOWN

TO: Ang F. Prager, Town Planzer

FROM: Cynthia G. Coliins, Lecal Counselor

BUBJECT: Impact Fees - Sweet Alien Farm

DATE: April 7, 1986

I have drawn up an educational impact agreement along the lines of the form used by Broward County. There are several problems and unarswered questions which need to be addressed.

The first guestion is Planoing Board authority to enter into this type of agreement. I have outlined the general law giving the Flanning Board authority to plan for facilities and our subdivision policy statement. At the moment this is all we have. Some type of directive, enactment, resolution, etc. from the Town Council, and ic our own reguiations, would be helpful. I have added to the agreement the Board's expectation of the adoption of impact fee regulations. As soon as possible, we need to strengthen the Board's authority to enter into these agreements (without enabling legislation).

The second question is the absence of impact fee schedules, which both the Board and the developer have a right to know. This agreement provides for payment of an amount in accordance with a schedule. Because there is no schedule adopted as yet, I have suggested that the developer be allowed to proceed if he chooses by posting a $\$ 500$ per unit security, with the possibility of. a rebate, if appropriate. This is only a suggestion. The most obvious alternative is to wait until we have better figures to work with.

The third question is the practical consideration of how the developer plans to provide for these fees. I have outlined a number of ways in number 4 of the agreement. This agreement calls for the up front posting of security by bond or escrow. However, a arrangement of recording this agreement as a lien on each lot until payment is made is also possible.

Finally, this agreement only addresses educational fees. Fees for water, sewer, recreation and transportation are also under consideration. The sweet Allen Farm plat will result in at least one identified road impact. From our discussions with the consultant on Friday, my understanding is the responsibility for impact to the roads, will have to be determined on an ad hoc basis rather than by formula. If the Town formalizes its environmental impact process, then it will be able to requife off-site road improvements. At the moment the developer has indicated a williggess to pay an amount for off-site road improvements. Impact fees will not address this area, and the Board sould simply use its judgement and attempt to get whatever it can until it has the chance to enact appropriate regulations. 
Town of South Kingstown

Legal Counselor -

Memo - Impact Fes/Sweet Alled Farm

Page 2

None of these questions need necessarily hold up the progress of Swet Alien Farm, as long as all parties are making an effort to agree on ali, cooperative resolution. If we cannot reach an agrement, wy suggstion is to take more time and operate from a surer footing than we now have.

$\therefore$ 
APPENDIX B

EDUCATIONAL IMPACT AGREEMENT

This is an Agreement between the Town of South Kingstown, a political subdivision of the state of Rhode Island, its successors and assigns, hereinafter referred to as the "TOWN" through its Planaing Board, and

its successors and assigns, hereinafter referred to as thé "DEVELOPEF."

WHEREAS, 545-22-7 of Rhode Island General Lawg provides that local plasijig boards are empowered to plan for the needs and resources of the community including but not limited to 45-22-7(3) - "Fublic facilities including recreationl areas, utilities, schools, fire stations, police stations and others."

WHEREAS, the subdivision Regulations of the Town require tre Planing Board to base its actions on subdivisions on enumerated policies including (7) "Adequacy of existing public improvemeats and services in the area, inciucing but not limited to water, sewer, drainage, roads, schools, recreation facilities and fire and police protection."

WHEREAS, the Flanaing Board is resolved that plats of resicential land shall be designed to provide for the educational needs of the future residents of the platted area in accord with impact fee reguiations, which it expects the fown to adopt in the near future.

WHEREAS, the Developer seeks to satisfy the anticipated educational impact fee requiremedt withirespect to Swoet Allen Farm Plat, which has been subritted for approval to the fladning Board by entering into this Educational Impact Agreewent for the payment of an amount of money to be utilized to meet the educational needs of the residents of the platted area; and

WHEFEAS, in description of the platted area is attached hereto as Exhibit "A" and made a part hereof; and

WHEREAS, the schedule and method of payment of such money and the provisions for its utilization prescribed herejo are appopriate to the circumstances of the specific developmest proposed for the platted area; Now, THEREFORE

In consideration of the mutual terms, conditions, prowises and payments hereinafter set forth, the fown and Developer agree as follows:

1. The Developer shall pay to the Town an amount of money in accordance with the schedule of payments contained in the Impact Fee Regulation adopted by the Towa. See Exhibit "B" attached hereto and wade a part hereof. 
2. The money paid by the Developer pursuant to this Agreement shall be used to provide educational facilities to serve students generated by new residential development in the Town.

3. The Tow agrees that this Agreement satisfies its requirements that pisis of residential land shall be designed to provide for the educational needs of future residents of the platted area.

4. The Developer shall provide the Town with a forw of security such as a cash bond, surety bond, letter of eredit or escrow agreement, which is acceptable to the rown, and which will guarantee the Developer's payment in full of the amount of money prescribed hereia. Evidence of such form of security shall be attached hereto as Exhibit "C" and made part hereof.

5. The Developer agrees that if at anytime the Developer is in default of this Agreement, the Town may expunge the plat referred to hereinabove from the official Records of the Town.

In witness whereof, the Town and Developer have uade and executed this Agreement or the respective dates under each signature.

Town

Town of South Kingstown through its Planing Board

ATTEST:

By:

day of 1986

\section{Developer}

Witnese

By and Through

Witness

day of 1986

Cooperate Seal 


\section{EXHIBIT B}

In the event that the Eeveloper wishes to proceed with the plat before achedule of impact fees has been edopted or is hereby agreed by the parties, that the Developer may provide secuirty in the amount of $\$ 500$ per housing unit.

It is urderstood by the parties that the $\$ 500$ figure is based on preliminary estimates and may result in a rebate to the Developer if the actual fee is lese than $\$ 500$. 

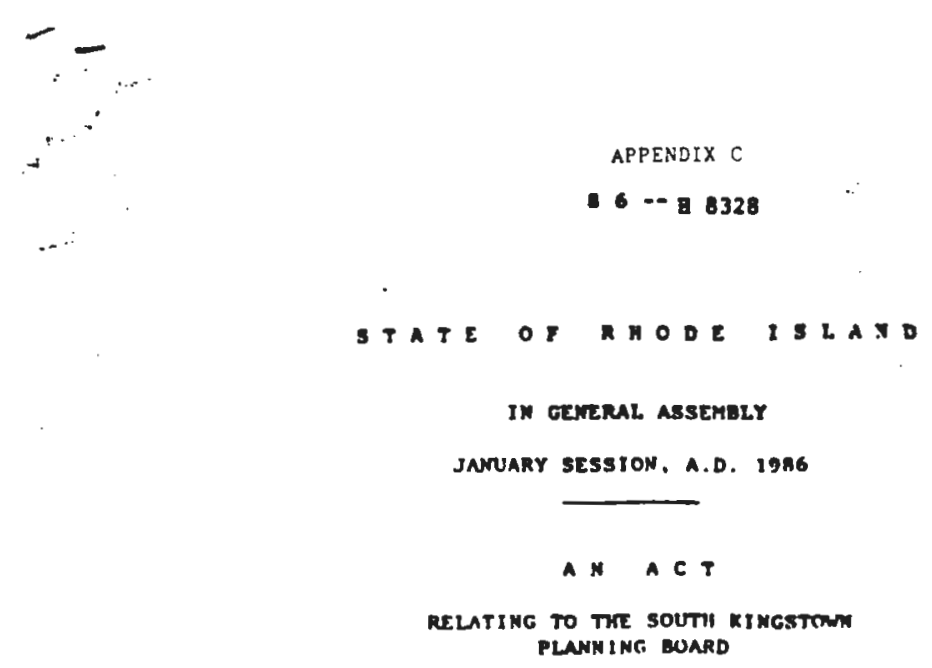

\section{PHDOE ISIAAND STATE LIBRARY}




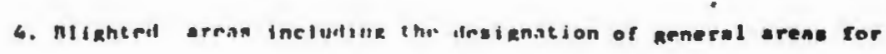
redevelopment, renewal, rehabilitative or conservation.

3. Problems of housing and the divelopment of houstng prosrame.

6. Envizonmental protection.

7. Natural reknurce conservation.

A. Procertion from diasalez.

n. Economic and anclel chis ietirtates of the populetion.

10. Preservation of hiftoric cicen and bulldinga.

i1. Economic development.

b. When difected by the eity or cown council or by the appolntine auehority, - plenning hoard or cmominaion whell prepere an ennual cepilst pudget and a comprehensive long range copilel improvement program for submingion to seid cotsnril, the appointine outhority or other desimniend official or mency.

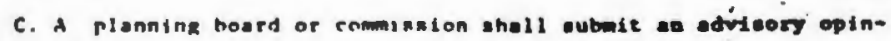
lon and recommontation on 11 zoning matera referzed to te under the provisione of the elty or cown zonine ordinance and aball repozt od nny other matcer referred to it. by the city or com council; the chiet executive or the eppointine atichority.

D. I Plannine honrd or rnmiasion whall perform such other duciete

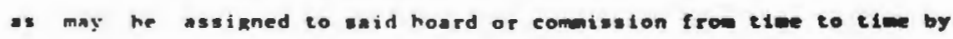
any net of the reneral assembly or by any ordinance, code, regulation order. or reselution of the city or coun. Eouncil ox by the sppointing nutheriey.

E. A planning boord or commission shell have outhortity to cali upon oeher departments, bourds and comittees of the city or tows and upon reasonal. state, and federal a pencies for informetoa and abiatance necesaery to the performance of lts dutipe and sholl cooperate with uch city or com, repinnal, state and federal esenctes oo are-" ters of communtey, resionel and steve planning and developmest.

F. The south Kingatown plonning hourd hell have authortey, for the purpose of assuring thot the phystesl developwent of the comanizr 
shall provide arequate public focilibles ineluding. but not areasere Ily limited to recreationel ereas, ulililien, achools, conde, police,

3 fire and neher mervices cufficient co provide for the requiremente of

4 the eroponed development.

3 G. The South Kingecown planning boerd shall huve autherlis to

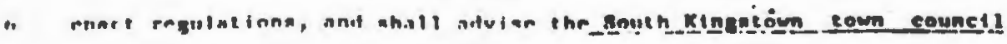

7 as to thnor mensuren neergenry carry oul the purpoges of this thape

- ter. including, but not necessarily 110 sed to the requiteme iog

- Iant developers to cantribute land for punlic tectlity or to con-

10 struct or expand or pay fee for the ecoulatclon of land or the con-

11 Eruction or expansion of suhlic faciliby. Any resuletions enected

12 or advice civen hy the plannint haned shall be reasonably reluced to

13 th: sublivinion or neher devel.roment under considerabion, and ant con:

is tribution $n$ f funts, land or puplis fnellities required trom the devel:

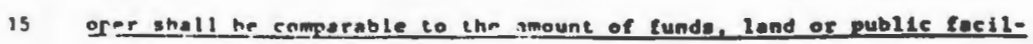

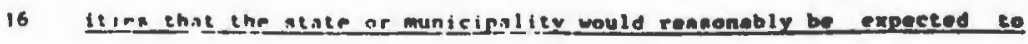

17 excent ar provide ss. reanlt of such subdiviston and developent, and

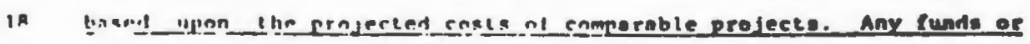

19 Junds rnntrihuted muse he expressy trsisned by the plenning beart and

2" shall he uritized to mitishtr thr impart upon the physicel, economte

21 and social erouth and devnlopment of the municipolity cearonably

22 aterimutable to the project.

23 SE.C?InN 2. This act shall take effect upon posaser. 

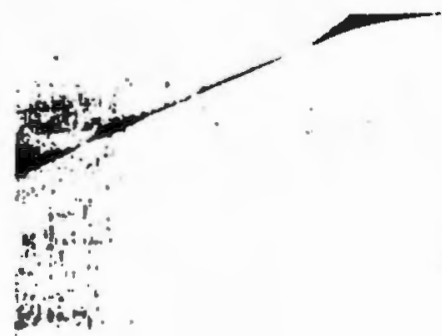

\section{EXPLANATIOY}

BY THE LEGISLATIVE COUỴCtL

\section{or}

AN ACT

RELATING TO THE SOUTH KIMGSTOWM

PLAMTING ROARD

$\rightarrow$

This oet rould eneble the South Kingetown plonning boerd to

2 enace subdivigion regulations and to advise the cowa councll

3 relative to the lapece of proposed subdivisions within tbe conm-

4 nity in order to eneure edequale public facilites and to require

5 Hedication of land or funds in an amount reosonobly releked io

b the subdivition or Aevelogment undet conaideration.

7 This ace would take effect upon passage. 


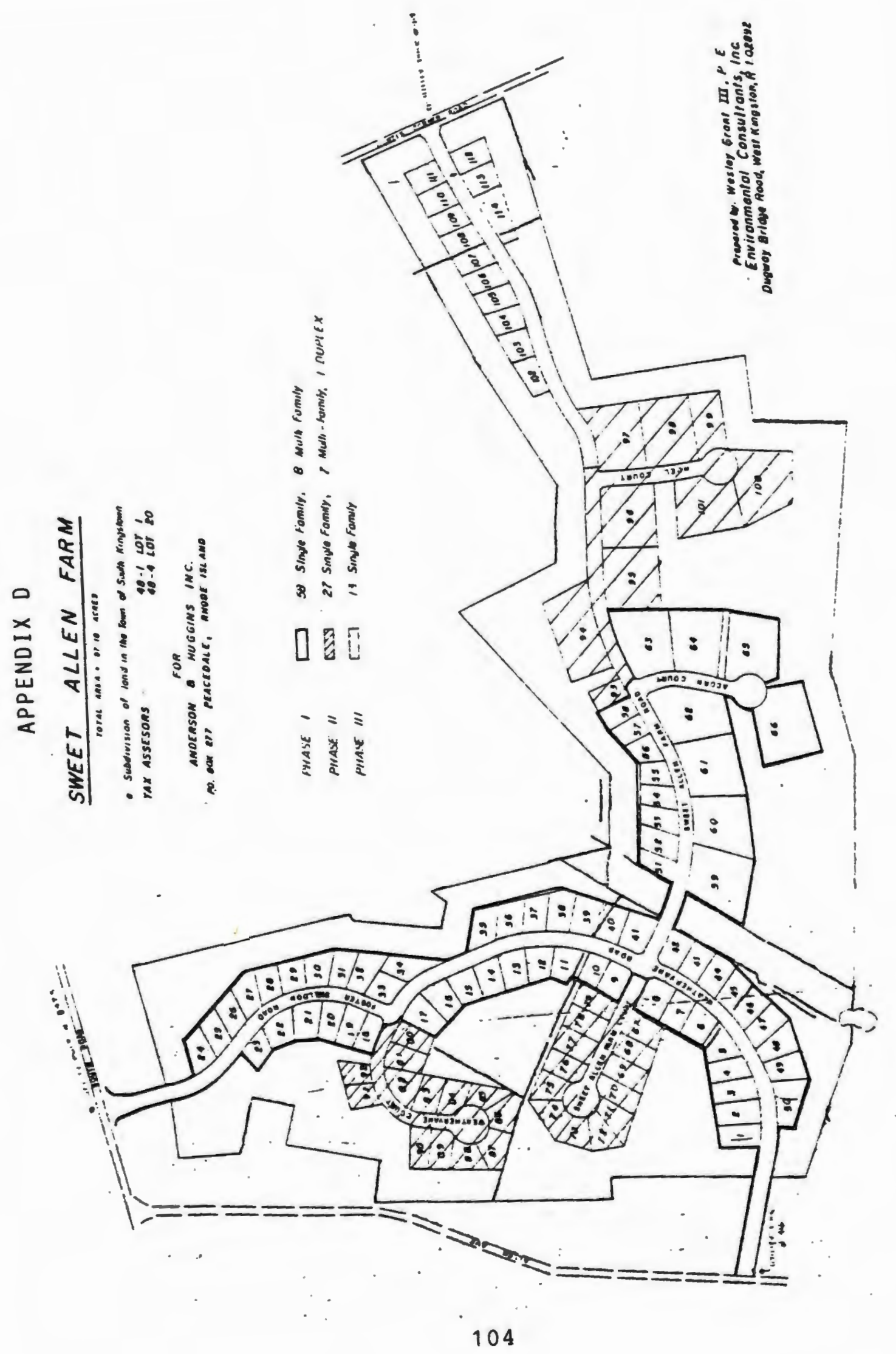




\section{BIBL IOGRAPHY}

Alfred, Steve. Town of South Kingstown, Wakefield, Rhode Island. Interview, Sept. 1985.

Frank Ansuini, Inc. v. City 으 ranston. 264 A. 2d 910 , Rhode Island, 1970 .

Beaverton, Oregon. Street Development Tax Ordinance. Ordinance Number 3010.

Bley, Kenneth. "Exactions in the 1980's," Proceedings of the Institute on Planning, zoning and Eminent Domain. The southeast Legal Foundation, Texas, Nov. $\overline{16-18,1983 .}$

Burchell, Robert W., and Listokin, David. The Fiscal Impact Handbook. Center for Urban Policy Research, New Brunswick, N.J., 1978.

Burrillville, Rhode Island. Payment in Lieu of Land for Recreation Act, Chapter 13 RIGL.

Cobb, Rodney L.; Jaffe, Martin; and Netter, Edith. Land Use Law and Zoning Digest.

Courier, Barry A. "Legal and Practical Problems Associated with Drafting Impact Fee Ordiances," Proceedings of the Institute on Planning, Zoning and Eminent Domain. The southeast Legal Foundation, Texas, Nov. 16-18, 1983 .

Davidson, Jonathan M. "Using Infrastructure Controls to Guide Development," Zoning and Planning Law Report, Vol. 8, No. 11, New York, N.Y., December 1985.

Duncan, James B. "Impact Fees: Requiring New Development to Pay its Own Way." National American Planning Association Conference, Montreal, Canada, 1984 (mimeographed).

Dunedin, Florida. Facilities Fee Act, Sections 26-136 through 26-145 of the Dunedin Code.

Gaston, James M. "Capital Recovery Fees: New Revenue for 
Texas Cities," Texas A\&M University System, April, 1983.

Glisson, Patrick C.; and Holley, Stephen H. "Developing Local Government User Charges: Technical and Policy Considerations," Government Finance, Vol. 11, Chicago, Ill., March 1982.

Hagman, Donald S. "Development Charges," State and Local Tax Revolt: New Directions for the $80^{\prime} \mathrm{s}$, Washington, D.C., 1978 .

Jacobsen, Fred; and Redding, Jeff. "Impact Taxes: Making Development Pay Its Way," North Carolina Law Review, vol. 55: 407-420, Chapel Hill, N.C., March 1977 .

Kory, Ross C.; and Rosenberg, Philip. "Costing Municipal Services," Government Finance, Chicago, Ill., Nov. 1977.

Lewis, Jonathan. "Proposition 13 Forces Shift to User Fees," State and Local Tax Revolt: New Directions for the $80^{\prime} s$, Washington, D.C., 1978.

Lord, Alan. South Kingstown Finance Department, Wakefield, Rhode Island. Interview, March, April 1986.

McRae, Robert D. "The Cost-Burden Study: A Method for Recovering Costs from Nonresidents," Government Finance, Chicago, Ill., Nov. 1977.

Mushkin, Selma J.; and Vehorn, Charles L. "User Fees and Charges," Government Finance, Chicago, Ill., Nov. 1977 .

National Center for Education Statistics. Projections of Education statistics to 1990-91, Vol. 1, Washington, D.C., 1982.

O'Connell, Daniel W.; and Schocch, Charles F. "Impact Fees: The Current state of the Law and Practice in Florida," APA Planning and Law Division Newsletter, Vol. 8, No. 2, Chicago, I11., March 1984 .

Pavelko, Thomas M. "Subdivision Exactions: A Review of Judicial Standards," Washington University Journal of Urban and Contemporary Law, Vol. 25: 269-294, st. Louis, Mo., 1983 .

Prager, Anna F. South Kingstown Planning Department, Wakefield, Rhode Island. Interview, Sept. 20, 1985; 
Jan. 26, 1986; April 5, 1986.

Rhodes, Robert M. "Impact Fees: The Cost-Benefit Dilemma in Florida," comment on Broward County $v_{0}$ Janis Development Corp.; and City of Dunedin v. Contractors and Builders Association of Pinellas County.

Silverstein, Rosalind; and Tegler, Philip. "Hartford Demands a Quid Pro Quo," Planning, Chicago, Ill., June 1985 .

Smith, Curtis. "Pinning Down Development Costs," Planning, Chicago, Ill., Dec. 1981.

Smith, Thomas. "Orange County's Road Impact Fees," APA zoning News, Chicago, Ill., July 1985.

Stewart, Harry. "How Road Impact Fees are Working in Broward County," Planning, Chicago, Ill., June 1984.

Tipps, Dean. State and Local Tax Revolt: New Directions for the $80^{\top} \mathrm{s}$, Washington, D.C., 1978.

USGAO, "User Charge Revenues," Report to the Congress, Washington, D.C., Dec. 2, 1981.

Vranicar, John. "Setting Zoning and Subdivision Fees: Making Ends Meet," APA PAS Report, No. 357, Chicago, Ill., Jan. 1981 .

Weitz, Stevenson. "Impact Fees: There is No Free. Lunch," Planning, Chicago, Ill., July 1984. 